\title{
Música, religião e produção social de espaço em uma cidade operária - o caso da igreja da pastora Ana Lúcia em Belford Roxo, Rio de Janeiro
}

\author{
Music, Religion and Social Production of Space in a Working-Class Town - the \\ case of the church of pastor Ana Lucia in Belford Roxo, Rio de Janeiro
}

\author{
Álvaro Neder \\ Universidade Federal do Estado do Rio de Janeiro, Rio de Janeiro, Brasil \\ alvaroneder@hotmail.com \\ Daniel Barros \\ Instituto Federal do Rio de Janeiro, Nilópolis, Rio de Janeiro, Brasil \\ Daniela França \\ Instituto Federal do Rio de Janeiro, Nilópolis, Rio de Janeiro, Brasil \\ Maria Clara de Matos \\ Instituto Federal do Rio de Janeiro, Nilópolis, Rio de Janeiro, Brasil
}

Mauricio Flora

Instituto Federal do Rio de Janeiro, Nilópolis, Rio de Janeiro, Brasil

Priscilla Sued

Instituto Federal do Rio de Janeiro, Nilópolis, Rio de Janeiro, Brasil

\section{Rodrigo Caetano}

Instituto Federal do Rio de Janeiro, Nilópolis, Rio de Janeiro, Brasil

\section{Rui Pereira Kopp}

Universidade Federal do Estado do Rio de Janeiro, Rio de Janeiro, Rio de Janeiro, Brasil

Resumo: A música utilizada em denominações religiosas neopentecostais está passando por diversas transformações na atualidade, deixando ver fissuras e heterogeneidades no que comumente se pensa ser um conjunto doutrinário relativamente coeso em torno de certos pressupostos tidos como indiscutíveis. Sustentamos aqui que a euforia em torno de um gênero musical surgido recentemente em certas igrejas neopentecostais, conhecido como "corinho de fogo" - aqui estudado em uma das primeiras abordagens na literatura acadêmica, senão a primeira -, representa uma tendência de grande propagação entre os fiéis dessas 
NEDER, Álvaro; et al. (2016) Música, religião e produção social de espaço em uma cidade operária - o caso da igreja da pastora Ana Lúcia em Belford Roxo, Rio de Janeiro. Per Musi. Ed. por Fausto Borém, Eduardo Rosse e Débora Borburema. Belo Horizonte: UFMG, n.34, p.132-176.

igrejas, e que envolve inclusive questionamentos à exclusão racial e desigualdade de classe. Como evidência, apresentamos o caso da igreja dirigida pela pastora Ana Lúcia. Localizada na cidade de Belford Roxo (Baixada Fluminense, RJ), em região de extrema pobreza, a igreja atrai principalmente fiéis de famílias de baixa renda, predominantemente de raça negra. Nos cultos da pastora, uma exuberante corporalidade negra se alia a uma música fortemente percussiva que é, juntamente com a dança, bastante evocativa dos rituais religiosos afro-brasileiros. Justamente por isso, a igreja, a pastora e seus fiéis e colaboradores sofrem críticas violentas, sem se deixar intimidar por isso, de fiéis e pastores de outras vertentes protestantes. Os resultados desta pesquisa evidenciam um caso específico de uma nova tendência entre as denominações neopentecostais, que vem acirrando de maneira verificável a heterogeneidade existente entre estas denominações, possibilitando que seus fiéis questionem fundamentos doutrinários em favor de lutas sociais e culturais que consideram urgentes. A agência coletiva de fiéis, músicos e pastores constituiu a igreja da pastora Ana Lúcia em um território social produzido ativa e afirmativamente como resposta e desafio à exclusão e preconceito, no qual a música é parte fundamental. A partir deste espaço musical e religioso, esse coletivo luta simbolicamente pelos direitos de inclusão e cidadania, e pelo respeito por suas crenças e práticas.

\section{Palavras-chave: Etnomusicologia participativa; Baixada Fluminense;} Neopentecostalismo.

Abstract: The music used in neo-Pentecostal denominations is undergoing several transformations today, revealing cracks and heterogeneities that contradict what is commonly thought to be a relatively cohesive doctrinal set around certain assumptions regarded as indisputable. We argue here that the euphoria around a musical genre that emerged recently in certain neo-Pentecostal churches, known as "corinho de fogo" - here studied in one of the first approaches in the academic literature, if not the first - represents a trend of large spread between the faithful of these churches, and includes issues of racial exclusion and class inequality. As evidence, we present the case of the church led by Pastor Ana Lucia. Located in the city of Belford Roxo (in the Baixada Fluminense, a metropolitan area of Rio de Janeiro), in a region of extreme poverty, the church attracts mostly low-income, predominantly black families. In the services of the pastor, an exuberant black corporeality is placed together with a heavily percussive music that is, along with the dance, very evocative of African-Brazilian religious rituals. Because of such practices, the pastor, the church members and collaborators, however unwavering, endure violent criticism from members and pastors of other churches. Thus, our results show a specific case of a new trend among the neo-Pentecostal denominations, which is intensifying the heterogeneity within these denominations, allowing the faithful to question doctrinal foundations in favor of social and cultural struggles they consider urgent. The collective agency of the church members, musicians and pastors constituted the temple of pastor Ana Lucia's into a social territory produced actively and positively in response and challenge to the exclusion and prejudice, of which music is a fundamental part. From this musical and religious space, this collective symbolically fights for the rights of inclusion and citizenship, and for respect for their beliefs and practices. 
NEDER, Álvaro; et al. (2016) Música, religião e produção social de espaço em uma cidade operária - o caso da igreja da pastora Ana Lúcia em Belford Roxo, Rio de Janeiro. Per Musi. Ed. por Fausto Borém, Eduardo Rosse e Débora Borburema. Belo Horizonte: UFMG, n.34, p.132-176.

Keywords: Participatory Ethnomusicology; Baixada Fluminense in Rio; NeoPentecostalism.

Data de recebimento: $11 / 02 / 2016$

Data de aprovação final: 06/04/2016

\section{1 - Introdução}

As relações entre pentecostalismo e o movimento negro no Brasil vêm sendo marcadas por conflitos, devido a causas variadas. Segundo levantamento do antropólogo John BURDICK (2001, p.187-188), envolvem os vínculos históricos do cristianismo com a escravidão (HOORNAERT, 1978; MOURA, 1994); o assimilacionismo, principal marca da conversão religiosa, com a adoção de traços culturais brancos e concomitante esvaziamento do discurso da diferença negra (Passos, citado por BURDICK, 2001, p.188); a ênfase no individualismo, com a desconsideração da questão étnica, forçosamente coletiva; e, finalmente,

\footnotetext{
a identificação do movimento negro com as religiões de origem africana, como fonte essencial de identidade e orgulho negro, é diretamente atingida pelos ataques do pentecostalismo a essas religiões, que as qualifica de bruxaria e de obra do demônio. (BURDICK, 2001, p.188)
}

Por mais que estas críticas sejam válidas, no entanto, uma perspectiva política progressista e favorável à transformação da situação social do negro no Brasil dificilmente poderia viabilizar-se sem dialogar com o pentecostalismo. Isto porque, em termos demográficos, o movimento religioso pentecostal é o mais importante do Brasil (BURDICK, 2001, p.188) e porque, de cada quatro pessoas que se identificam como negras "e estão se convertendo ao protestantismo, três vão para as igrejas pentecostais e uma para as igrejas tradicionais" (BURDICK, 2001, p.189).

Desejando, assim, contribuir para o diálogo entre o movimento negro e o movimento religioso neopentecostal, Burdick procura ressaltar, não os impasses consideráveis existentes entre as duas instâncias, mas as complexidades que permitem a 
NEDER, Álvaro; et al. (2016) Música, religião e produção social de espaço em uma cidade operária - o caso da igreja da pastora Ana Lúcia em Belford Roxo, Rio de Janeiro. Per Musi. Ed. por Fausto Borém, Eduardo Rosse e Débora Borburema. Belo Horizonte: UFMG, n.34, p.132-176.

confluência de interesses entre elas. Sugerindo que "há mais espaço para diálogo sobre [...] [a] questão [racial] do que até hoje se pensava ser desejável ou possível", Burdick se insere em uma vertente de pesquisadores que vêm buscando compreender os espaços existentes para práticas progressistas no interior do pentecostalismo.

Outra representante dessa vertente é a antropóloga Márcia Leitão Pinheiro. Em seu ensaio "Dinâmicas da religiosidade: experiências musicais, cor e noção de sagrado" (PINHEIRO, 2009), mesmo reconhecendo que "no meio protestante são veiculadas vozes e práticas que se opõem àquilo considerado de procedência afro-brasileira, além de atribuir um valor negativo ao seu conteúdo religioso e cultural", Pinheiro busca demonstrar “[as] falas sobre 'música negra', as peculiaridades daqueles que a divulgam e dos 'negros' [que] descortinam as continuidades, as rupturas e as tensões com as diretrizes vigentes (PINHEIRO, 2009, p.70). E continua:

\footnotetext{
Vê-se que produtores, cantores, pastores e leigos, integrantes ou não dos fóruns [da internet], dialogam com os princípios institucionalizados e procuram circunscrever um modo de pertencimento e participação demarcado por outros sentidos e imagens daquilo apontado como "negro" e "africano". Os integrantes dos fóruns falam de sentimentos, da invisibilidade do "negro" na teologia, na capacidade de cantar, de se relacionar com o sagrado e de estabelecer uma liturgia "com a nossa cara.... com muita música", quer seja a celebração realizada por mulheres ou por homens. Para isso, faz-se a defesa da releitura bíblica, de repensar a teologia e, ainda mais, alinhar as "ações de reparação" (de alcance social, político, histórico e religioso). Esperam atingir o fortalecimento de fiéis, do contingente de evangélicos "negros" ou "afro-descendentes", dos símbolos e das manifestações culturais com eles relacionadas. (PINHEIRO, 2009, p.70-71)
}

Portanto, Pinheiro, assim como Burdick, não tenciona defender a viabilidade de um movimento afirmativo exclusivamente negro dentro do movimento pentecostal, mas atestar uma nova tendência em que as diretrizes teológicas dominantes, que buscam deslegitimar a diferença negra, são tensionadas - de dentro, mesmo, das igrejas neopentecostais - pelos discursos e práticas de novos atores, participantes dessas igrejas, comprometidos em algum grau com essa diferença:

O que se pode observar com os depoimentos e com as atividades aqui elencadas é que a "África" surge como referência e, por conseguinte, fala-se em "negro", em "africano", em "afro- 


\begin{abstract}
descendente", de sua espiritualidade, a fim de constituir a experiência religiosa e, ao mesmo tempo, destaca-se outra elaboração de sagrado. Trata-se de uma dimensão inclusiva porque as diferenças não são subsumidas (cor, gênero e raça) e, muito menos, enfatiza-se o distanciamento de manifestações populares e religiosas, principalmente aquelas relacionadas com as populações afro-descendentes [...]. Ao focalizar as elaborações dos envolvidos com a "música negra" e com os fóruns, entende-se que o sagrado é aquilo que contempla o diverso e, assim, a música percussiva, a dança, o canto, a profecia, o louvor não são somente as expressões das "raízes africanas". Como componentes e expressões do sagrado, embasam a (re)leitura do Evangelho, e se integram à liturgia contextualizada. (PINHEIRO, 2009, p.71)
\end{abstract}

Colocando-nos no interior deste conjunto de pesquisas que buscam facilitar o diálogo entre o movimento negro e o movimento pentecostal, sustentamos aqui que a euforia em torno de um gênero musical surgido recentemente em certas igrejas neopentecostais, conhecido como "corinho de fogo", representa uma tendência de grande propagação entre os fiéis dessas igrejas, e que envolve inclusive questionamentos à exclusão racial e desigualdade de classe. Dada a referida importância demográfica do pentecostalismo no Brasil, essa tendência se torna sugestiva de possíveis transformações em larga escala na maneira como as populações negras refletem sobre seu lugar social, justificando um exame de suas diferentes manifestações.

Neste trabalho, apresentamos o caso da Igreja Pentecostal do Evangelho Pleno, dirigida pela pastora Ana Lúcia. Localizada na cidade de Belford Roxo (Baixada Fluminense, RJ), em região de extrema pobreza, a igreja atrai principalmente fiéis de famílias de baixa renda, predominantemente de raça negra. Nos cultos da pastora, corporalidade, música e dança são marcadamente baseadas em traços culturais autorreferenciados pelos participantes à cultura negra, o que produz pronunciada tensão no interior do movimento neopentecostal, atraindo críticas violentas de fiéis e pastores de outras vertentes protestantes e ressaltando a disposição agonística e a agência dos membros dessa igreja.

\title{
2 - Contexto geográfico e social da Baixada Fluminense
}


NEDER, Álvaro; et al. (2016) Música, religião e produção social de espaço em uma cidade operária - o caso da igreja da pastora Ana Lúcia em Belford Roxo, Rio de Janeiro. Per Musi. Ed. por Fausto Borém, Eduardo Rosse e Débora Borburema. Belo Horizonte: UFMG, n.34, p.132-176.

A Baixada Fluminense (BF), região metropolitana do Estado do Rio de Janeiro, é composta por treze municípios - considerados "cidades-dormitório", por sua estrutura deficiente e função principal de acomodar trabalhadores de baixa renda que atendam a metrópole -, onde vivem aproximadamente 3,5 milhões de habitantes.

Em Belford Roxo, o município da Baixada que nos interessará principalmente aqui, por abrigar a igreja da pastora Ana Lúcia, “o peso da indústria no PIB, em termos absolutos e reais é significativo [...] (SIMÕES, 2011, p.203)”. Num trecho de pouco mais de dois quilômetros, "encontramos os grandes empreendimentos: o Supermercado Carrefour e dois centros de logística, o Dutra Distribution Park e a Itapemirim Cargas. [...] "[L]ogo após a ferrovia, fica o complexo industrial da Bayer do Brasil [...], que se estende por quase dois quilômetros de extensão e é responsável por boa parte do PIB do município (SIMÕES, 2011, p.297). Esta predominância da atividade industrial na constituição da receita municipal justifica o uso do termo "cidade operária" no título deste artigo, mesmo que as atividades dos moradores sejam muito diversificadas, não se prendendo unicamente ao trabalho operário no setor secundário. Ao mesmo tempo, confrontada com a pobreza evidente da região, a riqueza gerada pela indústria ressalta o problema da desigualdade em Belford Roxo e na Baixada Fluminense.

Mesmo não existindo uma elite local em número suficiente para a constituição de bairros ricos, "a existência de um grupo muito numeroso de pobres faz surgir bairros de 'pobres'” (SIMÕES, 2011, p.299), sendo que a igreja aqui considerada, juntamente com os membros de sua congregação, localiza-se exatamente em uma dessas áreas de exclusão. A formação de bairros pobres é indicativa da má distribuição de renda entre setores abastados e pobres da população (uma vez que não se trata de município improdutivo, pelo contrário), e também do abandono do poder público, pois existe efetiva arrecadação de impostos que, no entanto, não são revertidos, em sua integralidade, em benefícios aos residentes. 
NEDER, Álvaro; et al. (2016) Música, religião e produção social de espaço em uma cidade operária - o caso da igreja da pastora Ana Lúcia em Belford Roxo, Rio de Janeiro. Per Musi. Ed. por Fausto Borém, Eduardo Rosse e Débora Borburema. Belo Horizonte: UFMG, n.34, p.132-176.

Um outro problema associado às questões da marginalização e desigualdade é o do estigma da Baixada como lugar da ausência e da negatividade. Apesar de sua produção cultural extremamente rica, a Baixada sofre, há décadas - conforme constatam os membros de nosso grupo de pesquisa residentes da região - , com a negligência dos governos e representações negativas da grande mídia, que disseminou a noção de que este extenso território se define unicamente pela violência e falta de manifestações de criatividade e positividade.

\section{3 - $\quad$ Rede EscutaBaixada e etnomusicologia participativa}

Buscando questionar tais representações, o grupo de pesquisa Rede EscutaBaixada, formado por estudantes - em sua maioria residentes da Baixada - dos cursos de graduação em Música da Universidade Federal do Estado do Rio de Janeiro (UNIRIO) e em Produção Cultural do Instituto Federal de Educação, Ciência e Tecnologia do Rio de Janeiro/IFRJ (Nilópolis, BF), vem desenvolvendo, desde 2011, um projeto de etnomusicologia participativa que busca se contrapor aos discursos do senso comum sobre a região.

O objetivo geral do projeto é etnografar as práticas musicais locais por meio das quais grupos excluídos contestam, respondem ou se reinventam frente às diversas formas de exclusão na região da Baixada Fluminense. São, também, utilizados registros audiovisuais, visando a produção de documentários (ver, por exemplo, CARDOSO, L.; TEIXEIRA, L.; LUZ, L. et al., 2013; e NEDER, A.; BARROS, D.; CAETANO, R. MATOS, M.C.; KOPP, R.P.; FRANÇA, D.; SUED, P.; FLORA, M., 2014), que são apresentados aos residentes da Baixada no âmbito dos programas de extensão federal Proext 2014 e Proext 2015 (MEC). Por meio dos debates gerados por esta integração pesquisa-extensão, a população residente intervém ativamente sobre os rumos da investigação, ressaltando aspectos de seu interesse, criticando representações eventualmente inadequadas e, de maneira geral, orientando a pesquisa. 
NEDER, Álvaro; et al. (2016) Música, religião e produção social de espaço em uma cidade operária - o caso da igreja da pastora Ana Lúcia em Belford Roxo, Rio de Janeiro. Per Musi. Ed. por Fausto Borém, Eduardo Rosse e Débora Borburema. Belo Horizonte: UFMG, n.34, p.132-176.

No subprojeto aqui apresentado, o foco é a produção social do espaço por meio da música na igreja dirigida pela pastora Ana Lúcia, já mencionada. A igreja pequena e humilde de Belford Roxo, assemelhando-se à grande maioria das residências do entorno, atrai fiéis de famílias operárias, predominantemente de raça negra e origem migrante nordestina. É conspícua a influência da música dessa região (forró) na sonoridade dessa igreja.

Da mesma maneira, os padrões fortemente percussivos, os altos volumes de instrumentos e cantores (sendo a principal intérprete e compositora a pastora Ana Lúcia) e a corporalidade de seus cultos em tudo se opõem aos padrões dominantes evangélicos pentecostais, aproximando-se de maneira paradoxal e intrigante àqueles praticados em religiões de matriz afro-brasileira. A corporalidade e musicalidade exuberantes da pastora, de suas composições e de seus músicos, inclusive, valeram um convite para participação no popular programa "Esquenta", apresentado pela animadora Regina Casé na TV Globo, veiculado no dia 1o de janeiro de 2012. Esta edição do programa teve um viés ecumênico, tendo nela se apresentado também representantes de outras religiões, inclusive afro-brasileiras, e nessa ocasião a pastora realmente "esquentou" a plateia e os outros participantes, que dançaram com muita animação. Tal aparição em um programa popular de televisão gerou acima de um milhão de visualizações em um dos vídeos da pastora no Youtube (ANA LÚCIA, 2010).

Frente a este contexto, nossa questão de investigação é se a música, ocupando evidente centralidade nos cultos da igreja, estaria sendo usada para transgredir normas de exclusão racial e a combater preconceitos de raça, classe e gênero, contribuindo para a produção de um espaço social onde ocorreria um fortalecimento da disposição de luta contra a discriminação por parte de seus frequentadores.

Outras questões correlatas que surgiram no decorrer da investigação foram: por que os membros da igreja se comportam dessa maneira? Qual seria a razão para a 
NEDER, Álvaro; et al. (2016) Música, religião e produção social de espaço em uma cidade operária - o caso da igreja da pastora Ana Lúcia em Belford Roxo, Rio de Janeiro. Per Musi. Ed. por Fausto Borém, Eduardo Rosse e Débora Borburema. Belo Horizonte: UFMG, n.34, p.132-176.

preferência, por parte dos fiéis, por esse templo em particular, uma vez que, na mesma região em que se localiza, existem numerosas outras igrejas? Quais seriam as relações dos membros da igreja, se alguma, com religiões de matriz afrobrasileira? Estaria a acontecer uma relação de acolhimento dos fiéis por parte da igreja, que permitisse compreender a preferência desses fiéis por esta igreja em termos de identificação racial, de classe, etc.? Que gêneros musicais são encontrados nessa igreja, e como os fiéis os significam diferencialmente? Existem questões de gênero permeando outros conflitos, como de classe ou raça?

Portanto, o objetivo geral deste subprojeto é investigar as práticas musicais da Igreja Pentecostal do Evangelho Pleno atentando para a maneira como questões de raça, exclusão e desigualdade em geral são abordadas por meio destas práticas.

\section{4 - $\quad$ Aspectos teórico-metodológicos}

Nesta pesquisa etnomusicológica, foi utilizado o método etnográfico, em sua modalidade participativa (FREIRE, 1970 e 1996) e de pesquisa-ação (THIOLLENT, 2008), além de técnicas de análise musical e entrevistas. Como um grupo de pesquisa formado, em parte, por residentes da Baixada Fluminense interessados em estudar a própria região urbana em que habitam, consultamos com interesse trabalhos que se orientam segundo essas linhas (ARAÚJO, 2006, 2009; CAMBRIA, 2004; MUSICULTURA, 2008).

Outra questão teórico-metodológica fundamental neste trabalho diz respeito à premissa de que a responsabilidade pela produção social da música é coletiva. Por extensão, também o é o espaço produzido pela música e ideologias circulantes. Usualmente, apenas os compositores, regentes, arranjadores, orquestradores, músicos e cantores são vistos como responsáveis pela criação musical, e ao público ouvinte é reservado um papel passivo. Esta maneira de pensar conduziria a uma visão equivocada da música na igreja da pastora Ana Lucia, como uma iniciativa vinda "de cima", de líderes que "controlam" tal produção, quando o que desejamos 
NEDER, Álvaro; et al. (2016) Música, religião e produção social de espaço em uma cidade operária - o caso da igreja da pastora Ana Lúcia em Belford Roxo, Rio de Janeiro. Per Musi. Ed. por Fausto Borém, Eduardo Rosse e Débora Borburema. Belo Horizonte: UFMG, n.34, p.132-176.

ressaltar é a produção coletiva, horizontal e comunitária do espaço social por meio da música.

A contrapelo das ideologias burguesas que concentram a invenção da música unicamente na figura do compositor ou líder, vários teóricos têm-se distinguido na compreensão da cultura em geral, e da música em particular, como produto de toda uma comunidade, não de indivíduos privilegiados. Tomemos, inicialmente, o filósofo e sociólogo Cornelius CASTORIADIS (1991, 1992,1995). Castoriadis afirma a criação imotivada das instituições por parte do coletivo anônimo - por intermédio do imaginário social - como o fundamento da sociedade, contra tudo o que foi já teorizado como tal: leis da história, da economia, da natureza e mesmo da razão. A sociedade é criação, criação dela mesma: autocriação, diz. Portanto, em oposição a teorias que pretendem enxergar "indivíduos notáveis" como orientadores da marcha da história, o pensamento de Castoriadis nos ajuda a entender o papel produtivo das massas anônimas.

Por sua vez, para o etnomusicólogo Christopher SMALL $(1987,1999)$, que cunhou o conceito de "musicar" para se referir à música por meio de um verbo de ação, ao invés de usar um substantivo descritivo, o que entendemos como música é produzido coletivamente. Isto seria evidenciado pelo fato de que a recepção (ou seja, a significação produzida pelas pessoas comuns) de toda performance retroalimenta a própria performance e futuras performances.

Já para a teoria da mediação de Adorno, os efeitos da obra sobre o receptor “dependem de inúmeros mecanismos de difusão, de controle social e de autoridade [...], dos estados de consciência e inconsciência - que são socialmente determinados" (ADORNO, 1986, p.108), sendo apenas um aspecto da totalidade social em que obra, autor e receptor estão inseridos.

Também em uma visada sociológica, Antoine HENNION contribui para desconstruir a ideia de um suposto controle por parte de instâncias autorais, bem como da 
NEDER, Álvaro; et al. (2016) Música, religião e produção social de espaço em uma cidade operária - o caso da igreja da pastora Ana Lúcia em Belford Roxo, Rio de Janeiro. Per Musi. Ed. por Fausto Borém, Eduardo Rosse e Débora Borburema. Belo Horizonte: UFMG, n.34, p.132-176.

autonomia da "obra", situando a produção simbólica sempre num terreno coletivo de luta (HENNION, 2002).

No entanto, talvez mais eloquente no contexto aqui em questão seria o trabalho de pós-estruturalistas como a psicanalista e crítica literária Julia Kristeva e o crítico literário Silviano Santiago. Para Kristeva, as linguagens ditas “artísticas” não são produzidas por uma instância autoral transcendental - ela prefere "sujeito da escrita", uma vez que o termo "autor" salientaria a intenção consciente de um escritor que teria autoridade sobre o sentido de sua obra. A ideia de "sujeito da escrita" enfatiza a relação de subordinação que um escritor (ou compositor) tem com a cultura - todos os produtores precisam lançar mão de materiais e ideologias que os superam, antecedem, e são, necessariamente, coletivos. Sem pretender negar toda intencionalidade ou importância da pessoa específica que produz uma obra, o ponto principal é que aquilo que se denomina usualmente um "autor" ou "eu" é um ponto axial situado no interior de uma matriz de enunciação (KRISTEVA, 1974, p.87; ver, também Kristeva 1969, 1975, 1976, 1980, 1989, 1998a, 1998b; e GUBERMAN, 1996). De maneira correlata, Santiago, em seu famoso artigo Caetano enquanto superastro (SANTIAGO, 2000), coloca autores/intérpretes como meramente um discurso do coletivo. Por esta óptica, o trabalho de líderes como Caetano Veloso e a pastora Ana Lúcia seria, principalmente, o de articular o desejo da comunidade a quem se dirigem e de quem são produtos, sendo seriamente problematizadas aspirações auráticas de criação individual. Acreditamos que esta visada seja mais apropriada para compreender a participação do coletivo anônimo na produção de um espaço social organizado, por meio da música, em torno de significações sociais e raciais, relativizando os papéis de liderança individual.

\section{5 - Histórico do Protestantismo e Neopentecostalismo no Brasil}

Para que se possa compreender adequadamente o contexto atual das discussões sobre música e desigualdade nas igrejas pentecostais, é preciso, antes, caracterizar 
NEDER, Álvaro; et al. (2016) Música, religião e produção social de espaço em uma cidade operária - o caso da igreja da pastora Ana Lúcia em Belford Roxo, Rio de Janeiro. Per Musi. Ed. por Fausto Borém, Eduardo Rosse e Débora Borburema. Belo Horizonte: UFMG, n.34, p.132-176.

sucintamente as diferentes denominações, surgidas em diferentes momentos do Protestantismo no Brasil. As igrejas apresentam características que as singularizam, o que produziu a necessidade de nomeá-las diferencialmente como históricas, pentecostais e neopentecostais.

As denominações que resultaram da Reforma Protestante desencadeada pelo monge alemão Martinho Lutero (1483-1546), são chamadas históricas. 0 protestantismo dito "histórico" foi implantado no Brasil pelas missões norteamericanas a partir da terceira década do século XIX (GOUVÊA, 2007, p.170-171). Encontrando uma cultura "inteiramente adversa" à sua, não lhe restou "senão ajustar-se [...] ou [...] manter-se à distância de práticas culturais contrastantes com a sua própria, bem como, na parte política, não se imiscuir em questões de Estado, inclusive no que dizia respeito à escravidão" (GOUVÊA, 2007, p.171). Segundo Gouvêa, essa evitação do debate político caracterizaria o protestantismo histórico:

\footnotetext{
Manter-se, por prudência ou conveniência diplomática, não fazendo críticas abertas ao Estado monárquico em favor da democracia republicana. Mesmo quando a República substituiu o Império, o júbilo dos missionários foi discreto. Daí o refrão tradicional entre os protestantes históricos: "o crente não deve se meter em política". (GOUVÊA, 2007, p.171)
}

Um outro momento propiciaria o surgimento das igrejas pentecostais, o que ocorre em 1910 com certas características "clássicas" que dizem respeito ao alinhamento às pregações pentecostais da Rua Azusa e de Chicago (CAMPOS, 2011, p.506).

0 pentecostalismo no Brasil sofreria uma forte modificação nos anos 1950, "como resultado do aumento da concorrência religiosa" (CAMPOS, 2011, p.514), quando obtiveram grande força novas igrejas surgidas nesse momento e caracterizadas pela ênfase na cura e nas manifestações do Espírito Santo (Pentecostes). Apresentando crescente abertura ao sincretismo e hibridação, o movimento pentecostal, finalmente, se abriria, nos anos 1970, a um estilhaçamento entre múltiplas denominações e orientações, conhecidas como "neopentecostalismo":

Uma segunda explosão pentecostal aconteceu nos anos 1950, voltando a desestabilizar as relações entre os evangélicos protestantes e pentecostais. As novas igrejas surgidas a partir 
NEDER, Álvaro; et al. (2016) Música, religião e produção social de espaço em uma cidade operária - o caso da igreja da pastora Ana Lúcia em Belford Roxo, Rio de Janeiro. Per Musi. Ed. por Fausto Borém, Eduardo Rosse e Débora Borburema. Belo Horizonte: UFMG, n.34, p.132-176.

daquela década faziam da cura divina, dos milagres e prodígios, o foco central de suas atividades. Desde então o subcampo evangélico brasileiro se tornou mais plural e competitivo, acirrando-se os processos de conflitos, acomodação e sincretismo. Essa situação se tornou mais visível após os anos 1970, quando um pentecostalismo com maior capacidade competitiva passou a levar vantagem na arena das denominações e igrejas cristãs. Esses neopentecostais cresceram em número, porém, ao ampliar os seus respectivos universos simbólicos, incorporaram símbolos, crenças e se tornaram portadores de teologias e discursos, híbridos e sincréticos. Uma quantidade enorme de trabalhos está sendo produzida a respeito desse pentecostalismo que Paul FRESTON (1993) considerou ser de "terceira onda", e Ricardo MARIANO (1999) e Leonildo CAMPOS (1997) chamaram de "neopentecostalismo". (CAMPOS, 2011, p.506)

Essa trajetória rumo à fragmentação crescente é também uma trajetória de progressiva integração entre o neopentecostalismo e a cultura popular brasileira:

O modelo protestante e inicial dos pentecostais, que privilegiava rupturas com a cultura popular brasileira, foi dando lugar a uma postura de continuidade que atingiria na expansão dos neopentecostais a sua mais alta expressão. (CAMPOS, 2011, p.515)

No entanto, é preciso notar que, em geral, essa estratégia neopentecostal se faz à custa do apagamento e ocultação dos laços entre as manifestações culturais e suas origens étnicas, notadamente afro-brasileiras, como observou o antropólogo Vagner Gonçalves da Silva (SILVA, 2007) a respeito do carnaval, do samba e da capoeira. Tendo em vista as fortes relações entre a música, a dança e a corporalidade na igreja da pastora Ana Lucia e a ancestralidade negra, nos deteremos nessa questão adiante.

Outra importante característica das novas transformações, às quais o neopentecostalismo estaria melhor adaptado do que as correntes protestantes "históricas", diz respeito ao que vem sendo descrito há algumas décadas como pósmodernidade:

[...] foi surgindo uma "religiosidade protestante mínima", popular, com fronteiras fluidas, remarcadas ao sabor das necessidades sócio-psicológicas dos pobres, excluídos e "sobrantes" da vida moderna e pós-moderna. Essa "nova" religiosidade introduziu uma lógica eliminadora das certezas absolutas, das fidelidades até a morte às instituições e sistemas religiosos. Essa "fidelidade" permanente passou a ser vista como resquícios descartáveis de outros tempos e lugares. 0 estudo desse tema tem despertado a atenção de sociólogos da religião que ao estudarem o dinamismo do fenômeno religioso valorizam, atualmente, o caráter nômade da 
NEDER, Álvaro; et al. (2016) Música, religião e produção social de espaço em uma cidade operária - o caso da igreja da pastora Ana Lúcia em Belford Roxo, Rio de Janeiro. Per Musi. Ed. por Fausto Borém, Eduardo Rosse e Débora Borburema. Belo Horizonte: UFMG, n.34, p.132-176.

religiosidade que extrapola os limites da instituição e do campo religioso. (CAMPOS, 2011, p.515-516)

Assim, as fidelidades, outrora mantidas pelo crente com relação à instituição eclesiástica, dão lugar a fidelidades transitórias, ligadas à contextualização (aproximação das práticas religiosas à realidade sociocultural da congregação) e aos líderes religiosos, como a pastora Ana Lúcia aqui em debate:

\begin{abstract}
Para evitar esse processo de "liquidificação" do religioso, uma das formas tidas como acertadas é introduzir a lealdade pessoal aos líderes carismáticos, os quais se tornam novos intermediáriosrearticuladores das relações humanas ao redor do sagrado. Como resultado desse processo, fronteiras desde há muito demarcadas, identidades tradicionalmente consagradas, se tornaram rapidamente irrelevantes. (CAMPOS, 2011, p.516)
\end{abstract}

Portanto, a caracterização de Campos permite entender a crescente relevância de igrejas como a da pastora Ana Lúcia como resultado de uma guinada imposta ao movimento religioso protestante no Brasil pela população do país. Tal guinada se processa sob o influxo de duas questões básicas. Uma delas é devida às transformações culturais globais impostas pela ordem econômica do capitalismo tardio, que fizeram desmoronar as certezas e permanências, inclusive as de cunho teológico, frente a um mundo inquietante em que tudo parece se desfazer a cada instante. A outra questão básica seria a necessidade sentida por esta população de um apoio, não mais de uma instituição universalista regida por princípios abstratos, mas de um líder espiritual de carne e osso, morador da região, conhecedor de sua realidade específica e diretamente implicado - inclusive em sua própria corporalidade - nos problemas sociais vividos pela comunidade. É esta proximidade e comprometimento da pastora Ana Lucia com sua congregação - que constatamos em nossa etnografia -, retribuídas por forte sentimento geral de representatividade da pastora e sua música, que permitem compreender essa igreja como um espaço em que a manifestação musical produzida coletivamente pela comunidade (cf. Christopher SMALL, "musicar") assume o papel de articular questões sociais e políticas (no sentido amplo) dessa comunidade. 


\section{6 - Contexto da música nas igrejas neopentecostais - "corinho" e "corinho de fogo"}

Segundo a cientista da religião Jacqueline Ziroldo DOLGHIE (2007, p.13), o culto protestante trazido ao Brasil pelos missionários norte-americanos não discutia os preceitos calvinistas na concepção musical. Como fruto dos movimentos de avivamento das "igrejas de fronteira" dos EUA, se reduzia a um extenso sermão acompanhado de hinos emocionais, tendo-se estruturado, portanto, em um modelo que esta autora denomina "bipolar": a prédica e a música. Uma vez que, naqueles primeiros tempos do protestantismo em terras nacionais, predominava o racionalismo, a música ocupava lugar subordinado ao sermão, considerado a parte principal do culto, e era organizada de maneira complementar e de reforço à palavra.

Na tipologia de João Wilson FAUSTINI (1973, p.12-16) para a música usada universalmente na igreja, a canção evangelística (gospel song) era o modelo que vinha sendo utilizado para popularizar as igrejas protestantes nos EUA e Inglaterra desde o século XIX. A canção evangelística passaria a ser, portanto, o modelo que seria implantado nas práticas protestantes no Brasil após a importação dessa religião, em substituição aos hinos tradicionais, mais longos, exigentes, difíceis de memorizar e afastados da realidade das populações mais pobres e menos escolarizadas.

A partir da canção evangelística, surgiria no Brasil, na década de 1950, conforme explica o historiador Éber Ferreira Silveira LIMA (1991, p.54), o corinho, que ressaltaria ainda mais esta característica de busca de contextualização e popularização. De acordo com Lima, “a expressão 'corinho', pelo próprio uso do diminutivo, quer demonstrar que ele é uma simplificação do simples; ou seja, dos coros, das canções mais populares até então usadas pela igreja" (LIMA, 1991, p.54). Este gênero musical tem as seguintes características, segundo o autor:

(a) os corinhos têm melodia simples, intuitiva; (b) são, em geral, curtos; (c) as letras usam uma linguagem coloquial; (d) o conteúdo apela mais para o emocional que para o racional; (e) por serem 
NEDER, Álvaro; et al. (2016) Música, religião e produção social de espaço em uma cidade operária - o caso da igreja da pastora Ana Lúcia em Belford Roxo, Rio de Janeiro. Per Musi. Ed. por Fausto Borém, Eduardo Rosse e Débora Borburema. Belo Horizonte: UFMG, n.34, p.132-176.

curtos, são facilmente memorizáveis; (f) são mais ritmados, lembrando música popular. (LIMA, 1991, p.54)

Inicialmente sendo utilizados em encontros informais de jovens (não nos cultos) (DOLGHIE, 2007, p.204), os corinhos gradualmente iniciam sua trajetória de sucesso, e, amparados por uma ideologia individualista, rapidamente se disseminam nos próprios cultos:

\footnotetext{
Enfrentando a oposição dos tradicionalistas, os corinhos acabaram por incorporar-se ao uso das igrejas locais, funcionando como uma espécie de válvula de escape jovem para os cultos bem comportados da maioria das igrejas. É evidente que, sendo fruto de uma teologia fundamentalista e de uma noção intimista de evangelho, tais corinhos falam de salvação individual, piedade pessoal e esperança para o porvir, não dando importância a questão contextuais. (LIMA, 1991, p.54-55)
}

Em vista do caráter individualista imputado por Lima aos corinhos como um todo a partir de suas letras, chamamos a atenção, aqui, para a importância de se considerar a música dos corinhos e seus sentidos para as populações implicadas, em vez de fixar-se apenas no texto linguístico. Este movimento é o que nos propomos neste trabalho (e em todas as vezes que analisamos canções populares). Ao fazer esse exercício, constatamos que a mensagem dos corinhos deixa de ser unívoca, não obstante o tom conformista do sentido verbal, e abre-se a possibilidade de considerarmos críticas sociais não veiculadas explicitamente pelas letras, mas igualmente presentes na performance dos corinhos.

Em meados dos anos 1970, surge o "cântico", que Dolghie considera "uma segunda geração do corinho". Nesse mesmo período aparecem grupos brasileiros que se iniciam na composição (mesmo que o estilo musical continuasse preso ao norteamericano) e composições utilizando gêneros brasileiros, como o baião. Entretanto, mesmo depois da introdução dos corinhos e dos cânticos, Dolghie acredita que o protestantismo de missão continuou a caracterizar-se pela negação à cultura local, pelo individualismo e pelo distanciamento das questões sociais, submetendo a juventude protestante do país à alienação social e cultural (DOLGHIE, 2007, p.208209). 
NEDER, Álvaro; et al. (2016) Música, religião e produção social de espaço em uma cidade operária - o caso da igreja da pastora Ana Lúcia em Belford Roxo, Rio de Janeiro. Per Musi. Ed. por Fausto Borém, Eduardo Rosse e Débora Borburema. Belo Horizonte: UFMG, n.34, p.132-176.

A multiplicação dos gêneros utilizados na música evangélica, sejam brasileiros como

o samba, axé, pagode, sertanejo, forró e outros, sejam o rap, funk, etc., está fortemente associada ao termo gospel pelas revistas evangélicas especializadas. 0 uso desse termo no Brasil passou a dar-se na década de 1990, por meio da ação da Igreja Apostólica Renascer em Cristo (Renascer), e Dolghie percebe nesse uso uma forte vinculação mercadológica:

A Renascer patenteou a marca [gospel] no Brasil e criou um contingente de produtos gospel: Gospel Records, Revista Gospel, TV Gospel e outros. A atuação desta igreja foi muito importante para a constituição de um mercado fonográfico brasileiro que abrangesse a juventude evangélica. 0 mercado firmou-se definitivamente no país, e aqui encontramos a caracterização da música gospel que é exatamente a sua concepção mercadológica. Assumimos o pressuposto de que a música gospel é uma produção do protestantismo e do neopentecostalismo, cuja característica distintiva está na relação intrínseca com o mercado. [...] Nos Estados Unidos, [o termo gospel] representa estilo musical, que, por sua vez, gera um mercado fonográfico específico. Entretanto, no Brasil, o conceito música gospel refere-se a uma variedade enorme de estilos musicais. Aqui, portanto, o termo relacionou-se com o mercado e desvinculou-se do estilo musical. (DOLGHIE, 2007, p.196-197, ênfases no original)

Portanto, o gospel

explodiu na última década do século XX entre os evangélicos e deu forma a um modo de vida configurado pela tríade música-consumo e entretenimento. Esse modo de vida se expressa, especialmente, em novas formas de culto religioso e na relativização da ética protestante restritiva de costumes. A referida tríade é caracterizada pelas transformações advindas do reprocessamento das culturas das mídias, urbana e de mercado entre os evangélicos e da busca de superação da crise entre protestantismo e sociedade que tem marcado a história deste segmento no Brasil. Entretanto, a análise embasada nos estudos culturais e nas ciências da religião revelou que esses traços de modernidade da cultura gospel estão entrecruzados com a tradição, com a conservação de traços da identidade protestante no Brasil como o dualismo igreja vs. mundo, o individualismo, o intimismo religioso, o sectarismo, a rejeição da diversidade de manifestações culturais e religiosas, o antiecumenismo e o antiintelectualismo. (CUNHA, 2004, s.p.)

É nesse contexto que Márcia Pinheiro fala da black gospel music, que se aproxima do fenômeno do qual desejamos nos acercar, a música na igreja da pastora Ana Lúcia:

No âmbito evangélico são encontrados também os especialistas que afirmam formular e oferecer "música negra", às vezes nomeada "música afro", ou black gospel music, integrada por musicalidades percussivas, componentes e expressões da rota diaspórica (Gilroy, 
NEDER, Álvaro; et al. (2016) Música, religião e produção social de espaço em uma cidade operária - o caso da igreja da pastora Ana Lúcia em Belford Roxo, Rio de Janeiro. Per Musi. Ed. por Fausto Borém, Eduardo Rosse e Débora Borburema. Belo Horizonte: UFMG, n.34, p.132-176.

2001), como, por exemplo, o hip-hop, o samba, o pagode, o rhythm and blues ( $r \& b)$, o soul e o reggae, apontadas pelos entrevistados como componentes e reveladoras das histórias e das religiosidades dos povos negros. Nesse caso, sublinham o "sofrimento" e o "cativeiro", como condições extremas aplicadas aos escravos e aos descendentes; também enfatizam a fé, o canto e a dança como características das culturas de matriz africana [...]. Assim, a maioria dos profissionais considera a "música negra" adequada para estabelecer um canal conveniente de expressão religiosa, de contato com Deus, de evangelização de fiéis e ainda atuar em prol da valorização de artistas com ela envolvidos. (PINHEIRO, 2009, p.62)

Observe-se que surge, aqui, uma possibilidade de enxergar na música gospel uma crítica social feita pelos negros evangélicos ao racismo, bem como uma valorização, por parte desses mesmos atores, dos traços negros (p.ex., a fé, a música, o canto e a dança):

\begin{abstract}
Além dos produtores de "música negra", há ainda outros leigos e pastores que destacam a história, a religiosidade e as expressões culturais de [matriz] afrobrasileira, veiculando explicações acerca da "cultura negra" e da "cultura africana". Também debatem sobre a questão racial, especificamente as relações e imagens que se refiram àqueles considerados e autodefinidos brancos e negros e integrantes do meio protestante. Esses religiosos participam do Fórum Permanente de Mulheres Negras Cristãs (FPMNC), organizador do Fórum de Música Negra Brasileira e Igreja (FMNBI), e do Fórum de Lideranças Negras Evangélicas (FLNE), implementando também atividades e discussões sobre a "música negra", as condições e as imagens relacionadas à religiosidade de afro-descendentes. (PINHEIRO, 2009, p.63)
\end{abstract}

Mesmo assim, a autora ressalta o caráter minoritário dessas manifestações, bem como o antagonismo sofrido por elas no meio evangélico brasileiro:

Sobre a "música negra", pode-se afirmar que os fazeres citados não são majoritários e vigoram num meio que registra oposição e distanciamento das expressões religiosas e culturais de matriz africana ou afro-brasileiras. Estas são consideradas negativas, pois malignas e oriundas da "África", vista como região de idolatria. (PINHEIRO, 2009, p.63)

Apesar de não identificar uma ampla aceitação do discurso da diferença negra entre as igrejas neopentecostais, Pinheiro ressalta, com Burdick e outros autores, a necessidade de ver sutilezas e certa permeabilidade no movimento evangélico como um todo, opondo-se à perspectiva mais disseminada de uma religião homogênea e monolítica: 
NEDER, Álvaro; et al. (2016) Música, religião e produção social de espaço em uma cidade operária - o caso da igreja da pastora Ana Lúcia em Belford Roxo, Rio de Janeiro. Per Musi. Ed. por Fausto Borém, Eduardo Rosse e Débora Borburema. Belo Horizonte: UFMG, n.34, p.132-176.

[Essas] expressões religiosas e culturais, ditas "negras", "afro", ou afro-descendentes, revelam não ser o meio evangélico constituído por rígidas oposições; essas e outras iniciativas compõem e expressam os encontros culturais e religiosos, sendo a musicalidade um aspecto. Pode-se falar, então, em diálogos, contatos fronteiriços, fluxos, ligações e ressignificações (BIRMAN, 1996; SANCHIS, 1999; BURDICK, 2002; SILVA, 2007). (PINHEIRO, 2009, p.63)

\section{7 - $\quad 0$ “Corinho de Fogo”}

Um outro gênero musical que surge da linhagem aqui traçada é o chamado "corinho de fogo". Trata-se de um fenômeno ainda muito pouco estudado - se é que já estudado antes - sendo que não conseguimos localizar um único trabalho sobre este gênero na literatura acadêmica. 0 descompasso entre os estudos acadêmicos e a sociedade é visível nesse caso, pois uma pesquisa pela palavra-chave "corinho de fogo" nos buscadores da internet fornece dezenas ou centenas de páginas com debates apaixonados entre fiéis favoráveis e contrários a esta música e práticas relacionadas, coletâneas de letras, videoclipes e gravações de áudio com fartura de exemplos de músicas, shows, CDs e DVDs com esta denominação de gênero, evidenciando sua larga e não tão recente popularidade através do país.

A Wikipedia, no verbete "Corinhos", limita-se a declarar: "Existe hoje em dia a designação 'Corinhos de Fogo' que tem um forte aspecto litúrgico de Batalha Espiritual, Batismo de Fogo e Exorcismo" (CORINHOS, 2014). Esta definição não é correta, pelo menos no que tange à igreja aqui estudada, uma vez que tanto na observação participante, quanto nas diversas entrevistas realizadas com fiéis, pastores, músicos e a própria pastora Ana Lúcia não foi encontrado absolutamente nenhum sinal de batalha espiritual contra outras religiões (notadamente afrobrasileiras). Ao contrário, os entrevistados frequentemente referem laços antigos, familiares com o Candomblé ou a doutrina espírita. Acreditamos que a maior parte dos fiéis de outras denominações neopentecostais que promovem a batalha espiritual também provêm dos mesmos segmentos culturais, sociais e raciais dos membros da igreja da pastora Ana Lúcia. Entretanto, estes últimos desenvolvem atitude mais tolerante com relação às religiões afro-brasileiras, valorizando mais os 
NEDER, Álvaro; et al. (2016) Música, religião e produção social de espaço em uma cidade operária - o caso da igreja da pastora Ana Lúcia em Belford Roxo, Rio de Janeiro. Per Musi. Ed. por Fausto Borém, Eduardo Rosse e Débora Borburema. Belo Horizonte: UFMG, n.34, p.132-176.

laços familiares e de amizade com os devotos dessas religiões do que os objetivos estratégicos (notadamente, disputas por adeptos) que se escondem por trás da batalha espiritual (a esse respeito, a pastora Ana Lúcia declarou em entrevista que "amizade é tudo"; outros membros da igreja entrevistados declararam que possuem parentes e/ou amigos que são fiéis do Candomblé ou espiritismo, sem que isso se coloque como obstáculo às relações afetivas).

Em termos de definições nativas do corinho de fogo (não nos referimos, aqui, à grande quantidade de críticas ferozes ao gênero), apenas pudemos colher na internet a seguinte (transcrita ipsis literis):

\begin{abstract}
kkkkkk é na igreja na verdade tem umas expressões unicas!!! como todo segmento temos expressões pra dizer sobre algo. Quanto ao corinho de fogo kk, é o seguinte: na verdade quer dizer corinhos avivados, ou seja, com certeza tua amiga tem o desprendimento suficiente pra cantar estes tipos de corinhos. Olha te digo que não é mesmo qualquer um que canta viu?!!! a pessoa tem que ser de "fogo" também senão o corinho fica apagadokkk, o corinho é pra avivar o povo, pra tirar a quietude do pessoal, o silêncio total, e dar um despertamento , muito bacana este chamado que tua amiga tem. Fiquem com Deus! (ANAVI, 2014)
\end{abstract}

Sendo poucas as informações gerais que pudemos obter a respeito do gênero corinho de fogo - principal sustentáculo da performance musical da pastora Ana Lúcia e de sua igreja - deixaremos a análise do gênero, em sua manifestação nessa igreja, para a seção seguinte.

Portanto, as transformações ocorridas no protestantismo brasileiro que se quis aqui resumir, sob influxos globais, nacionais e locais os mais variados, proporcionam um contexto para a compreensão da diferença proposta pela pastora Ana Lúcia em sua igreja, cujo caso passamos a examinar.

\title{
8 - $\quad 0$ “Corinho de Fogo” na igreja da pastora Ana Lúcia
}

A Igreja Pentecostal do Evangelho Pleno, que é coordenada pela pastora Ana Lúcia, localiza-se na Rua Caminho do Jambuí, número 130, no bairro Vilar Novo, numa região bastante empobrecida do município de Belford Roxo, na Baixada Fluminense. 
NEDER, Álvaro; et al. (2016) Música, religião e produção social de espaço em uma cidade operária - o caso da igreja da pastora Ana Lúcia em Belford Roxo, Rio de Janeiro. Per Musi. Ed. por Fausto Borém, Eduardo Rosse e Débora Borburema. Belo Horizonte: UFMG, n.34, p.132-176.

Há presença ostensiva da criminalidade fortemente armada nas cercanias da igreja, e entre seus "soldados", vários frequentam a igreja ocasionalmente. A rua tem iluminação e pavimentação precárias, com profusão de buracos e valetas. É composta, predominantemente, por residências, e o fluxo de carros, motocicletas e pessoas é baixo, sendo maior em seu início, onde se encontra a igreja. Os cultos acontecem às terças-feiras, quintas-feiras e domingos, de manhã e a partir de 19 horas, mas pelo que observamos o dia de maior frequência é quinta-feira à noite. É, também, o dia em que a música e a performance coletiva são mais animadas.

O primeiro contato com um culto da igreja em questão foi extremamente impactante, uma vez que seus corinhos de fogo se diferenciam radicalmente da música dos cultos evangélicos mais tradicionais (mesmo aqueles que, há décadas, adotam músicas populares). É bem verdade que este não é o único gênero de canção empregado na igreja, pois aquele conhecido como de "adoração" (músicas mais calmas, de caráter sentimental, usadas para louvar a Deus e/ou comunicar mensagens positivas de fortalecimento da vontade de superação) também é bastante presente. No entanto, focaremos nossa atenção no gênero "corinho de fogo" por nele estarem concentradas as características mais relevantes no que diz respeito a questões raciais.

Caracterizado por composições tonais com melodias e letras curtas, de fácil memorização, à base de gêneros afro-brasileiros, como samba, pagode e forró, os corinhos de fogo são executados com alta amplificação, acompanhados por instrumentos percussivos e embalados por andamentos moderados. Geralmente, o tonalismo é estruturado pelas escalas diatônicas maiores, com predominância da tonalidade de Mi maior, por se tratar de uma altura cômoda para que a pastora Ana Lúcia possa cantar, uma vez que, na maioria das vezes, é ela a compositora e quem inicia o canto dos corinhos. A vinculação da música à realidade social e cultural do público é expressa na estruturação melódica e harmônica, que foge de configurações complexas e virtuosísticas mais associadas à sala de concerto burguesa e suas derivações contemporâneas, inclusive de correntes majoritárias do próprio neopentecostalismo. Por isso, em muitos corinhos predominam as funções tônica, 
NEDER, Álvaro; et al. (2016) Música, religião e produção social de espaço em uma cidade operária - o caso da igreja da pastora Ana Lúcia em Belford Roxo, Rio de Janeiro. Per Musi. Ed. por Fausto Borém, Eduardo Rosse e Débora Borburema. Belo Horizonte: UFMG, n.34, p.132-176.

subdominante e dominante, como, por exemplo, no corinho "Boca do Sapo" (Figura 1):

\section{Boca do Sapo}

Corinho de Fogo
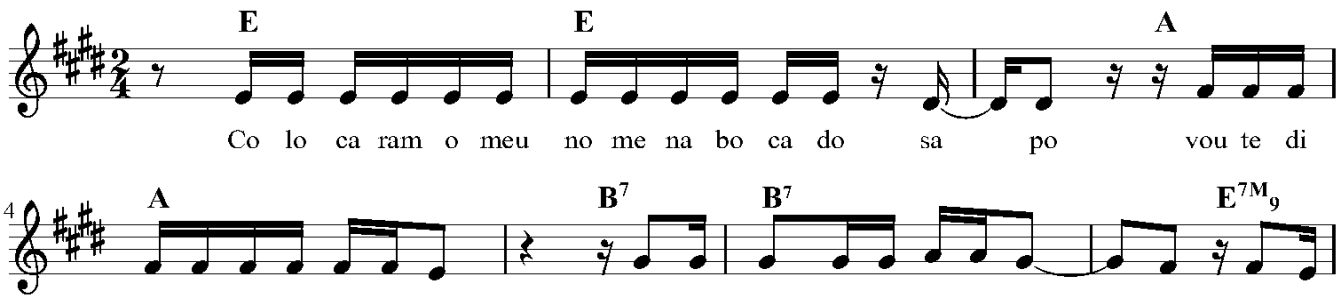

zer o que a con te ceu

O Se nhor me a ben ço o...

o e $\quad$ e

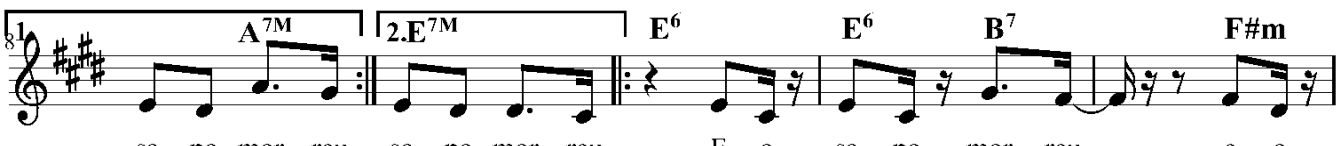

sa po mor reu sa po mor reu

E sa po mor reu

e 0
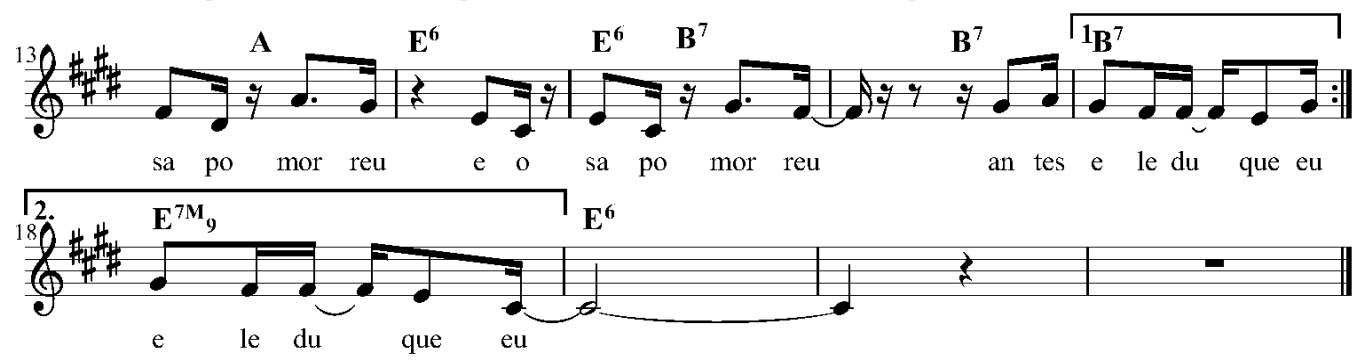

Figura 1: Corinho "Boca do Sapo"

A célula rítmica deste corinho (Figura 2) está estruturada pelo gênero forró, apresentando uma polirritmia complexa ao modo de outros gêneros afrobrasileiros, mais uma vez denotando a vinculação dessa música ao gosto musical dos estratos populares locais (inclusive, não se deve esquecer a forte migração nordestina constitutiva da população da Baixada Fluminense como um todo): 

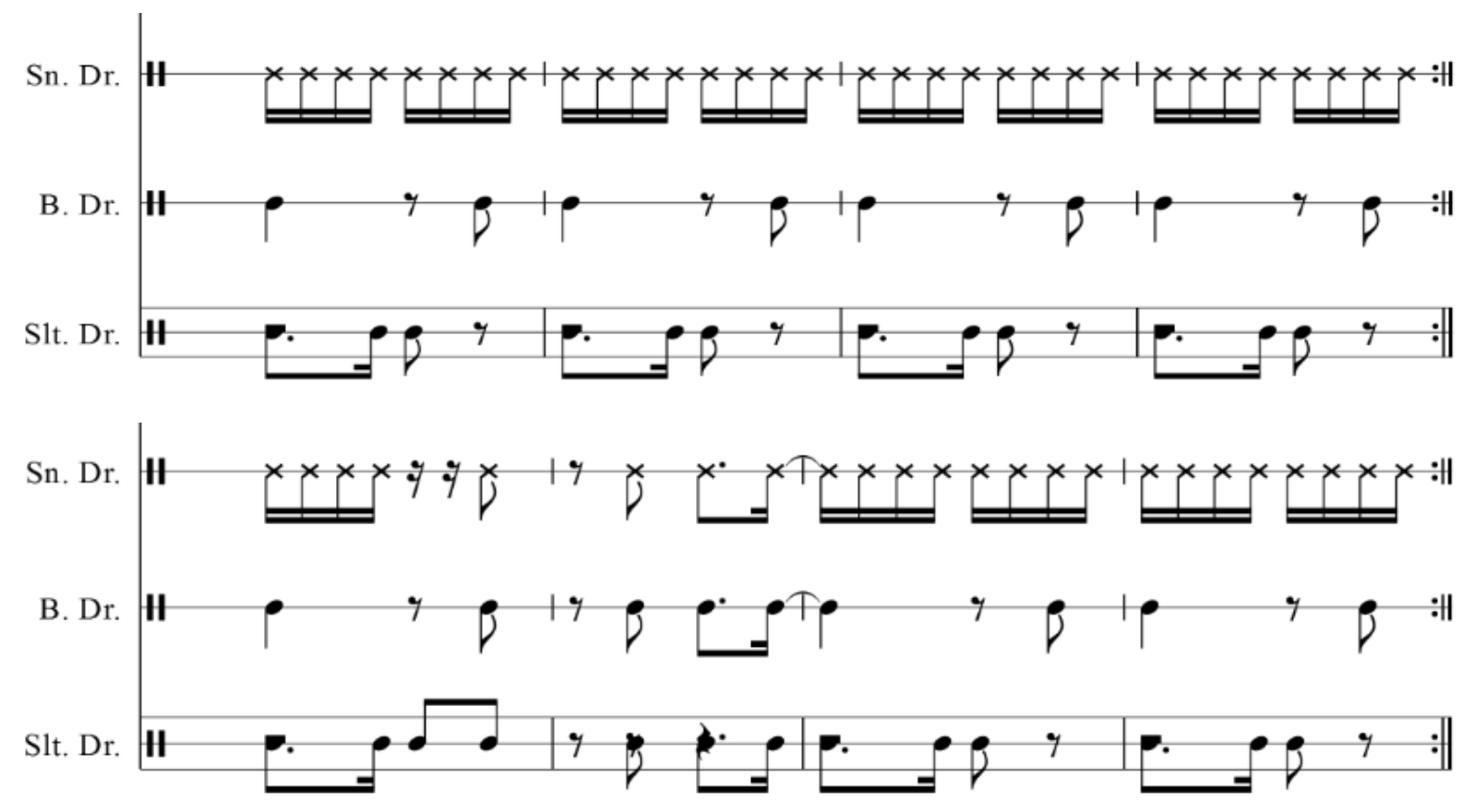

Figura 2: Rítmica do corinho "Boca do Sapo"

No entanto, um exame aprofundado das qualidades intrínsecas dos sons musicais teria que nos levar para além das categorias eurocêntricas e investigar as maneiras diferentes de estruturar o discurso musical encontradas entre os povos africanos e constitutivas da música negra na diáspora. Efeitos vocais especiais como vocalidade interpolada, guturalidade, falsete, blue notes, melismas, improvisação, vocalização rítmica; efeitos rítmicos estruturados por outra concepção métrica, concrescência e ruptura com a métrica e texturas antifônicas, homofônicas, polifônicas e heterofônicas forneceriam elementos mais enriquecedores para analisar a música aqui comentada.

Mais ainda, ao nos depararmos com a música dos corinhos de fogo da igreja da pastora Ana Lúcia, ficou evidente que seria inteiramente contraprodutiva uma abordagem musicológica de tipo tradicional, que buscasse isolar sons musicais de performances corporais, letras de músicas, interações entre o público e os pastoresmúsicos e, especialmente, dos sentidos que classificam, organizam e possibilitam a situação observada. Justamente por isso, a ideia de "música" deve ser permanentemente entendida entre aspas, pois certamente o que se entende pelo 
NEDER, Álvaro; et al. (2016) Música, religião e produção social de espaço em uma cidade operária - o caso da igreja da pastora Ana Lúcia em Belford Roxo, Rio de Janeiro. Per Musi. Ed. por Fausto Borém, Eduardo Rosse e Débora Borburema. Belo Horizonte: UFMG, n.34, p.132-176.

termo em certos grupos sociais seguramente não corresponde ao seu significado em outros grupos.

Por exemplo, o que seria, pelos critérios dos fiéis da pastora, "boa música", uma boa performance? Certamente não seria algo que se pudesse mensurar por critérios musicológicos mais tradicionais, que pudesse ser descrito unicamente em termos de características sonoras. Segundo os fiéis com quem conversamos, a "música" da pastora - por sua exuberância e expressividade - é indício confirmado da presença do Espírito Santo naquela igreja, enquanto que a "música" de outras igrejas - pela ausência das mesmas características, ou seja, por ser "apagada" - indicaria que a divindade não habitaria ali. Portanto, ainda que concordemos que a imediatez dos sons musicais seja considerada pelo membro da igreja parte fundamental da performance, se não houver a constatação, por parte do fiel, de que o Espírito Santo esteja presente, a "música" não será considerada satisfatória, ainda que os sons musicais pudessem ser considerados - por observadores externos - semelhantes aos encontrados em outro lugar. E, para que a "música" seja considerada satisfatória (i.e., que a presença do Espírito Santo seja constatada), é preciso toda uma convergência de sons musicais, letras de música e interações físicas, que incluem gestos e danças, e cada um destes elementos é mediado ideologicamente por discursos de identidade religiosa, racial e de classe.

Cabe observar, ainda que rapidamente, o papel das letras na construção dessa forma expressiva compósita. Observadas por critérios inadequados - os critérios de uma elite cultural - as letras parecem extremamente simples, como "Vem comigo dando glória/ Nessa noite de vitória/ Deus vai entrar dentro do teu lar/ A tua família Deus vai libertar". Tais letras, para além do significado verbal, possuem uma forma de estruturação que vem sendo descrita na literatura como associada historicamente aos povos da diáspora negra. Autores como o sociolinguista Roger D. ABRAHAMS (1976) e o crítico literário Henry Louis GATES (1988) se esforçaram por demonstrar uma outra lógica construtiva no discurso afro-estadunidense. Os linguistas diferenciam um "inglês negro" (Black English ou BE) de um "inglês padrão" (Standard English ou SE). Conforme o sumário de David BRACKETT, o "inglês negro" 
NEDER, Álvaro; et al. (2016) Música, religião e produção social de espaço em uma cidade operária - o caso da igreja da pastora Ana Lúcia em Belford Roxo, Rio de Janeiro. Per Musi. Ed. por Fausto Borém, Eduardo Rosse e Débora Borburema. Belo Horizonte: UFMG, n.34, p.132-176.

coloca ênfase no som das palavras $(B E)$, em vez de no seu sentido $(S E)$; o discurso é visto como uma performance, ou um jogo $(B E)$, em vez de como um ato de prestar informações $(S E)$; padrões de expressão sem distinções claras entre performer e público $(B E)$ em oposição a padrões de expressão com claras distinções entre ambas instâncias (SE) (BRACKETT, 2003, p.123). Gates teria incorporado na literatura este conhecimento trazido pela sociolinguística, compreendendo o signo linguístico negro em termos de uma ênfase nas relações paradigmáticas, ao contrário do inglês padrão, com sua ênfase comunicativa de teor "objetivo" recaindo sobre as relações sintagmáticas. Com isso, o significante linguístico na música negra é "musicalizado", deslocado do seu papel informativo para um papel performático, de jogo/brincadeira. Tais elementos são encontrados nas letras dos corinhos da pastora, e ainda outros, como o forte teor improvisacional de suas apresentações. A análise das letras demostra que elas sofrem considerável alteração de uma apresentação para outra, e esta prática improvisacional está bem documentada como característica da criação expressiva dos povos da diáspora negra (além de se enquadrar na categoria de jogo/brincadeira, no sumário acima). Portanto, estes desenvolvimentos no estudo das músicas e letras dos povos da diáspora se apresentam como importantes para uma análise mais detida e adequada de materiais como os aqui debatidos, para resultados mais condizentes com as propostas implícitas nestes fazeres outros. No entanto, por limitações de espaço, este exercício terá que ser realizado em outra oportunidade.

Muitos dos sons musicais, letras, interações físicas, gestos e danças encontrados na igreja da pastora são manifestações de corporalidade que habitam um outro universo semântico, associado às religiões afro-brasileiras (que, por sua vez, também são mediadas por discursos identitários de raça e classe), que saem do plano consciente (onde são renegadas, embora, às vezes, de maneira ambígua) mas, não obstante, permanecem ativas, de maneira subjacente, emprestando sua força para que ocorra a experiência de intensidade religiosa buscada ativamente pelo fiel. É essa adesão a uma identidade religiosa já mediada por uma identidade racial e de classe que se coloca no epicentro das fortes críticas recebidas pelos fiéis da pastora Ana Lúcia por membros e pastores de outras denominações, explicitando o caráter 
NEDER, Álvaro; et al. (2016) Música, religião e produção social de espaço em uma cidade operária - o caso da igreja da pastora Ana Lúcia em Belford Roxo, Rio de Janeiro. Per Musi. Ed. por Fausto Borém, Eduardo Rosse e Débora Borburema. Belo Horizonte: UFMG, n.34, p.132-176.

agônico, combativo, da opção por algo que poderia ser confundindo com uma "simples música", mas que está impregnada de significados identitários pelos quais se vive ou se morre. No caso, por meio da música, se constitui um espaço social de luta por direitos à inclusão social de pessoas discriminadas por seu baixo nível de renda, por sua baixa posição social, por sua raça.

É, justamente, esta discrepância entre conceitos de "música" - aquele presente em nosso cotidiano de matriz ocidental, inclusive acadêmico, e aqueles vivenciados por diversas populações, mesmo as constitutivas de nossa própria sociedade - que implica a necessidade de que o estudo de fenômenos "musicais" como o aqui destacado requeira procedimentos teórico-metodológicos específicos, que vão além do exame dos sons. Com efeito, muitas das tentativas dos pesquisadores voltadas para inquirir dos fiéis seus critérios de classificação puramente musical resultam infrutíferas, pois, para o crente, discutir, a propósito de uma música ou culto religioso, os sons musicais em separado dos sentidos religiosos seria empobrecedor e destituiria de valor toda a experiência.

O exame desta questão implica em denunciar o caráter propriamente etnocêntrico da noção de "música", o que tem sido feito por alguns etnomusicólogos, notadamente Bruno NETTL (1984; 2005, p.25-26), Kenneth GOURLAY (1984) e Samuel ARAÚJO (1992). Nettl lembra a histórica vinculação da etnomusicologia, nos tempos em que era conhecida como Musicologia Comparada, aos propósitos de uma antropologia ainda embebida de teorias evolucionistas e servil aos propósitos colonialistas (1984, p.39). Este paradigma dificilmente poderia levar a uma compreensão de diferentes modalidades expressivas sem esmagar suas especificidades sob um rótulo eurocêntrico, "música". Esta denúncia é feita por Gourlay, quando afirma que tal ideia de universalidade (reforçada pela onda de popularidade da "world music") se baseia na "concepção ocidental, que promove a ideia de que a música possui certas similaridades no mundo inteiro, similaridades que são espúrias porque nós [europeus] escolhemos ouvir apenas o que reforça esta concepção equivocada" (GOURLAY, 1984, p.32; citado por ARAÚJO, 1992, p.30). De acordo com Samuel Araújo, essa noção de "universalidade" da música busca, em 
NEDER, Álvaro; et al. (2016) Música, religião e produção social de espaço em uma cidade operária - o caso da igreja da pastora Ana Lúcia em Belford Roxo, Rio de Janeiro. Per Musi. Ed. por Fausto Borém, Eduardo Rosse e Débora Borburema. Belo Horizonte: UFMG, n.34, p.132-176.

última análise, "legitimar e reproduzir uma hierarquia entre formações sociais no interior de um dado campo de forças em conflito [struggling forces]" (Araújo, 1992, p.30). Buscando reposicionar a questão - e, com isso, reposicionando o campo etnomusicológico por inteiro - conclui Gourlay:

\begin{abstract}
Precisamos começar, não com a suposição de que alguma forma de "música", como a conhecemos, é universal, mas com a probabilidade maior de que a universalidade seja de alguma forma de expressão, para a qual, por enquanto, ainda não temos um nome [...], uma forma de expressão criativa que abranja o que é comumente designado por "som musical", "dança", "drama" e "ritual" (GOURLAY, 1984, p.36; citado por ARAÚJO, 1992, p.30)
\end{abstract}

Portanto, Nettl, Gourlay e Araújo nos trouxeram a um ponto a partir do qual é possível compreender a "música" no templo da pastora Ana Lúcia. Por esta concepção, o "som musical" não se separa da "dança", do "drama", do "ritual", dos significados religiosos e ideológicos, devendo a avaliação da performance ser capaz de correlacionar os elementos considerados significativos pelos nativos para que seja possível atingir tal compreensão.

Neste sentido, é de se notar a importância conferida pelos nativos aos elementos afro-brasileiros da performance - encontrados nos sons musicais, dança, gestualidade, oratória, na relação entre pastores e comunidade, enfim, numa multiplicidade de planos expressivos, mediados por identidades de raça, classe e cultura, todos reunidos naquela forma criativa a que Gourlay se refere e para a qual ainda não dispomos de um nome, optando por denominá-la provisoriamente de "música". Mesmo após termos relativizado a ideia de "música" como consistindo meramente de padrões sonoros, os depoimentos, transcritos a seguir, dos próprios fiéis, dos músicos da banda da pastora e da pastora colocam neste componente do fato cultural total - fortemente mediado por significados identitários negros - um peso extremamente elevado.

Por exemplo, o músico Gabriel Silva dos Santos declara que "se você se ligar você vai [perceber] o Espírito Santo na música que nós tocamos aqui, você tem que se ligar bastante, começar a dar glória, esse é o segredo, aqui você sente a presença dele". Perguntado como é possível sentir essa presença, se é pela animação da música, 
NEDER, Álvaro; et al. (2016) Música, religião e produção social de espaço em uma cidade operária - o caso da igreja da pastora Ana Lúcia em Belford Roxo, Rio de Janeiro. Per Musi. Ed. por Fausto Borém, Eduardo Rosse e Débora Borburema. Belo Horizonte: UFMG, n.34, p.132-176.

relaciona um conjunto de elementos que inclui a música mas vai além dela, abrangendo a força da pregação (um tema sempre lembrado pelos fiéis em geral), e uma "segurança" ou convicção difícil de segmentar analiticamente, mas passível de ser sentida pelo fiel participante do evento como um todo: "Pela animação, pelo jeito que é cantado, pelo jeito que é falado, a força que você faz pra... a segurança que você dá pra pessoa, a pessoa se liga diretamente no céu e você sente o Espírito Santo". Entretanto, valoriza a música como um componente destacado desta experiência, pois, respondendo sobre qual é a diferença entre os cultos sem música e com música, declara que, com a música, principalmente executada por uma banda, o fiel "se inspira mais":

\begin{abstract}
Ah, é muita diferença! Quinta-feira retrasada teve um culto que foi com música, todo mundo recebendo e tal; quinta-feira agora o culto foi sem música, todo mundo pra baixo, um pra cá, outro pra lá, um sentado assim, outro pra lá, não fica a mesma coisa de ter um acompanhamento, você cantando. Aqui você cantando sozinho, você se inspira um pouco, mas não com uma banda, entendeu, se inspira mais. (SANTOS, G., 2014)
\end{abstract}

O músico Aristides Cristóvão Nunes sugere uma relação entre música e ideologia dos fiéis, ao classificar as músicas das igrejas como passíveis de ser desejadas pelas pessoas ou não. E a questão racial, a seu ver, está implicada no envolvimento das pessoas, tanto com uma música quanto com uma determinada igreja:

[A música] ajuda as pessoas a se aproximarem. Muitas das vezes as pessoas chegam numa igreja e não tem aquele ritmo que ela quer, então [a música certa] envolve mais as pessoas na casa do Senhor, traz ela mais perto da salvação que elas estão querendo. Tem música que atrai mais as pessoas. [Você acha que isto está ligado à forma do negro se expressar?] Sim, o prazer, o amor que ele tem pela música, que ele está vendo, realizando, se envolvendo [...] Quando vou numa vigília com ela [a pastora Ana Lúcia] - que nem a última, eu tava cansado, mas o ritmo envolvente, tu chega lá com instrumento, aparelho de som, o ritmo é gostoso e tu começa a tocar e sente a coisa muito profunda mesmo. Ela mesma sabe, eu posso estar cansado mas chego aqui, envolvido pela música, o corinho [de fogo], e é uma coisa que quando você vai ver não tem mais cansaço não tem mais nada. Uma coisa que te envolve. [...] A gente tá querendo fazer um projeto aí nas esquinas, nas praças, todas as tardes, eu creio que o ritmo dos corinhos que a gente leva eu creio que muitas pessoas [podem se voltar] para a igreja, porque é um ritmo que todo mundo gosta [...] ainda mais quando ela [canta] "Vem comigo dando glória", é uma coisa fantástica mesmo. (NUNES, 2014) 
NEDER, Álvaro; et al. (2016) Música, religião e produção social de espaço em uma cidade operária - o caso da igreja da pastora Ana Lúcia em Belford Roxo, Rio de Janeiro. Per Musi. Ed. por Fausto Borém, Eduardo Rosse e Débora Borburema. Belo Horizonte: UFMG, n.34, p.132-176.

De maneira geral, as características afro-brasileiras exibidas pela pastora e a música de sua igreja - a exuberância corporal, o ritmo sacudido, a forte interação com o fiel todo o tempo, a pregação intensa, as relações subjacentes com as práticas religiosas tradicionais - são desejadas pelos fiéis como fonte de potência, uma energia necessária para lidar com as adversidades que os afligem. De acordo com o fiel Elton Silveira,

o corinho de fogo é mais agitado, as pessoas dão lugar ao Espírito Santo de Deus [...] Sem esse avivamento não tem como a igreja influir numa sociedade, no tráfico de drogas, porque esse impulso é o Espírito Santo [que] nos dá coragem e nos faz essa potência. (SILVEIRA, 2014)

O músico Albertinho Lima do Nascimento subscreve indiretamente esta visão ao arrolar gêneros afro-brasileiros como a música que "traz mais gente à igreja":

a gente toca um ritmo diferente, a gente toca tipo forró, às vezes axé, pagode, samba, de acordo com o que a pastora canta a gente toca. Tem adoração, corinho de fogo, pagode... [Essa música ajuda no trabalho de evangelização?] Ajuda, porque traz mais gente pra igreja, jovens, ajuda bastante, é animado, [o pessoal] dança [...] (NASCIMENTO, 2014)

Portanto, compreendendo a noção de "música" como um complexo de elementos, os fiéis procuram essa igreja por causa desta totalidade da qual o sonoro é o ponto nodal, índice verificável da presença do Espírito Santo. Podemos, então, concluir com segurança que a agência coletiva produz um espaço de relações sociais por meio da "música", e que a igreja da pastora é esse espaço.

Tendo demonstrado que a "música" atua de forma essencial na produção de um espaço social (religioso), buscaremos agora evidenciar, através de depoimentos dos participantes da igreja, que a questão racial negra é reconhecida por eles, que a igreja e a "música" são representativas de uma comunidade negra.

Como se sabe, os cultos neopentecostais predominantes no Brasil são extremamente rigorosos no disciplinar o corpo e no afastar-se das religiões e músicas de matriz afro-brasileira, consideradas fabricações do demônio. Segundo Silva, tais cultos, em geral, se caracterizam por traços em comum, inclusive a "centralidade da teologia da 
NEDER, Álvaro; et al. (2016) Música, religião e produção social de espaço em uma cidade operária - o caso da igreja da pastora Ana Lúcia em Belford Roxo, Rio de Janeiro. Per Musi. Ed. por Fausto Borém, Eduardo Rosse e Débora Borburema. Belo Horizonte: UFMG, n.34, p.132-176.

batalha espiritual contra as outras denominações religiosas, sobretudo as afrobrasileiras e o espiritismo" (SILVA, 2007, p.208). Sendo assim, a primeira interrogação que surgiu ao tomarmos contato com aquela igreja diz respeito ao caráter transgressor assumido pela música naquele espaço.

Durante a execução dos corinhos de fogo, causa espécie a performance corporal dos pastores e fiéis, que dançam e cantam energicamente numa aparente proximidade com as cerimônias realizadas em religiões afro-brasileiras. Essas semelhanças ficaram evidentes nas situações observadas. Em um dos cultos, por exemplo, duas jovens de aproximadamente 18 anos davam as mãos de olhos fechados e, em êxtase, curvavam-se e retornavam à postura ereta repetidas vezes, durante toda a execução de uma música. Enquanto isso, durante sua pregação, um dos pastores repetia: "Solta o grito e baixa!" para os fiéis que rodopiavam.

Tal performance corporal não é exclusiva dos cultos da igreja da pastora Ana Lúcia, muito pelo contrário. Trata-se de prática bastante disseminada nas igrejas evangélicas após a "terceira onda" neopentecostal que discutimos anteriormente, e é denominada pelos seus adeptos de "reteté":

\footnotetext{
"reteté" é um termo usado pelos pentecostais para falarmos que o culto "pegou fogo", ou qualquer outra forma de explicar um culto pentecostal, isso não significa que houve exageros nos cultos como há em alguns lugares ou coisas erradas que vemos por aí, mas é uma forma de nós pentecostais nos expressarmos. (O QUE SIGNIFICA “RETETÉ"?, 2014)
}

Há, na internet, inúmeras críticas de fiéis e pastores a esta prática, vista por eles como uma "manifestação do demônio", por estar, segundo tais críticos, vinculada às religiões afro-brasileiras como a Umbanda (chamadas, pejorativamente e de maneira genérica, de "macumba"). Por exemplo, na mesma página referenciada acima, encontramos uma postagem que diz: "Retété é uma coisa que os macumbeiro faz e eles chama de retété". Outra mensagem pergunta, "tem mesmo necessidade de por nomes de centro de macumbas em meio as coisas de Deus? [...]" Ainda outra postagem não utiliza o termo "macumba", mas faz a mesma associação negativa com as religiões afro-brasileiras: “Na palavra reteté vem dos escravos que vinheram da 
NEDER, Álvaro; et al. (2016) Música, religião e produção social de espaço em uma cidade operária - o caso da igreja da pastora Ana Lúcia em Belford Roxo, Rio de Janeiro. Per Musi. Ed. por Fausto Borém, Eduardo Rosse e Débora Borburema. Belo Horizonte: UFMG, n.34, p.132-176.

Africa era uma dança parecida com o chango [xangô] brasileiro pelos afrodescendentes, hoje vemos muitos grupo que dizem reteté de Jeova isso não é de Deus, ok." Tais críticas frequentemente se fazem acompanhar por vídeos comparativos que buscam comprovar tal vinculação, muitos deles, inclusive, filmados sem o consentimento dos fiéis, sejam da Umbanda, do Candomblé ou da religião evangélica. Devido a essa inadmissível falta ética, deixamos de referenciar tais vídeos.

Seja como for, as práticas religiosas neopentecostais sugerem fortemente influências arraigadas das religiões de matriz afro-brasileira, profundamente disseminadas entre a população. As religiões afro-brasileiras permaneceriam como modelo preferencial de adoração de muitos brasileiros e brasileiras, mormente os dos segmentos populares, mesmo quando, por motivos ainda não suficientemente explicados, decidem voltar-se para as religiões neopentecostais. Tivemos oportunidade, anteriormente, de rever, com Campos, que o neopentecostalismo promove uma continuidade com a cultura popular brasileira, em substituição à ruptura realizada pelo protestantismo e o primeiro pentecostalismo; e, com Silva, que esta continuidade se faz com o apagamento das origens étnicas afro-brasileiras. É nessa mesma direção que segue a compreensão da etnomusicóloga Angela Luhning:

[u]ltimamente, observa-se uma transformação em muitas das
diversas igrejas da religião cristã, católica ou
evangélica/protestante, recuperando exatamente estes aspectos
da religião afro-brasileira: a forte ligação da palavra coma música
e, especialmente, com a "linguagem" corporal. Esta inclusão do
musical e corporal, além da fala, da interpretação da palavra, é
certamente uma inclusão tardia dos elementos presentes nas
religiões afro-brasileiras, embora certamente não aconteça com a
consciência de um reconhecimento. Sabemos que essa inclusão
serve como base para uma interpretação negativa que oferece a
base para a própria condução do culto, em parte uma abertura para
um lado até então excluído, até para se tornarem mais atraentes,
porém sem aceitar a sua existência prévia nas religiões afro-
brasileiras. (LUHNING, 2001, p.30)

Entretanto, contrariamente à percepção de Luhning e dos outros pesquisadores citados anteriormente, verificamos, no caso dos membros da igreja aqui estudada, a valorização da ancestralidade negra. Efetivamente, para a pastora Ana Lucia, essa 
NEDER, Álvaro; et al. (2016) Música, religião e produção social de espaço em uma cidade operária - o caso da igreja da pastora Ana Lúcia em Belford Roxo, Rio de Janeiro. Per Musi. Ed. por Fausto Borém, Eduardo Rosse e Débora Borburema. Belo Horizonte: UFMG, n.34, p.132-176.

performance corporal é resultado, conforme ela própria declara, de toda sua vivência familiar:

Fui criada na Umbanda pela minha avó materna e a minha avó paterna era candomblecista, então nós ficamos ali dividida. Ela me puxava, minha avó me puxava pra um lado, [a outra avó] puxava pro outro, então eu fiquei sendo criada no Candomblé e na Umbanda. Então, ainda existem pessoas da minha família que são candomblecistas, que são umbandista, por isso que eu respeito, né? Porque a gente, é nossa origem, nós viemos de lá, e a gente sabe que tem que respeitar, né? (ANA LÚCIA, 2014)

É muito interessante notar a referência à "nossa origem" - ou seja, a origem negra, a cultura de ascendência africana. Uma marca extremamente relevante do pensamento da pastora Ana Lúcia, de vários de seus músicos, de seus fiéis, enfim, das visões circulantes na sua igreja, é o respeito e até mesmo a valorização dos traços afro-brasileiros, que são, em geral, menosprezados nas práticas neopentecostais. Conforme já foi dito anteriormente, a África é, em geral, vista pelos evangélicos como região de idolatria. Portanto, esta visão inclusiva e respeitosa voltada para a África e a cultura negra diaspórica é uma característica importante da igreja da pastora Ana Lúcia, e se opõe ao tratamento preconceituoso ou à espiral de silêncio dedicados aos traços culturais de origem africana por grande parte das denominações neopentecostais.

Sendo assim, os resultados obtidos junto à igreja aqui estudada se diferenciam de forma significativa dos constantes da maior parte da literatura consultada nesse sentido. Por exemplo, ao sintetizar as críticas do movimento negro aos problemas causados pela conversão de negros ao neopentecostalismo, Burdick aponta que

a principal marca da conversão religiosa é a adoção de uma série de traços culturais brancos, incluindo vestuário, gestos e música. Assim, o negro que se converte ao protestantismo passa por "um processo de auto-rejeição, de branqueamento, autonegação e alienação" (Passos, 1995, p.5). Em terceiro lugar, a fervorosa mescla pentecostalista de individualismo e universalismo é vista como oposta ao crescimento da identidade étnica. (BURDICK, 2001, p.188)

Em depoimento ao antropólogo, um militante negro explicitou tais problemas:

Eles [os pentecostais] são totalmente fechados à questão étnica, à questão racial. Só se importam com o indivíduo, não com o grupo. 
NEDER, Álvaro; et al. (2016) Música, religião e produção social de espaço em uma cidade operária - o caso da igreja da pastora Ana Lúcia em Belford Roxo, Rio de Janeiro. Per Musi. Ed. por Fausto Borém, Eduardo Rosse e Débora Borburema. Belo Horizonte: UFMG, n.34, p.132-176.

Ou então dizem que não há racismo entre eles, porque são todos irmãos. Tudo isso é muito bonito; assim eles negam a dinâmica do grupo étnico, negam até a existência do problema. (Militante anônimo, citado por BURDICK, 2001, p.188)

Conforme explicitaremos adiante por meio das declarações dos músicos, pastores, fiéis e da própria pastora Ana Lúcia, o que verificamos nessa igreja é uma situação radicalmente diferente. A contribuição positiva - o que é dizer, a diferença - das culturas afro-brasileiras é reconhecida e valorizada; são explicitamente nomeadas músicas negras, uma beleza negra, um orgulho negro, uma forma negra de se expressar. Até mesmo as formas de adoração produzidas pelas religiões afrobrasileiras, foco dos ataques da principal representante do segmento neopentecostal, a Igreja Universal do Reino de Deus, são valorizadas nos cultos da igreja, como vimos. Tudo isso conflui para a produção social de um espaço de afirmação negra por meio da música, nessa igreja.

No entanto, não obstante as semelhanças, influências e proximidades com as religiões de matriz afro-brasileira, a pastora e seus fiéis deixam bem claras as diferenças e descontinuidades, pois as práticas de adoração, ainda que semelhantes e até mesmo idênticas em sua exterioridade, são ressignificadas no plano discursivo, voltando-se exclusivamente para Deus, Jesus Cristo e o Espírito Santo. Devido a isto, as críticas frequentes e, muitas vezes, violentas, às práticas da igreja, provocam séria consternação entre seus membros, que se mostram entristecidos frente ao que consideram uma incompreensão da parte dos que atacam uma manifestação de adoração religiosa que desconhecem:

Quando entrei numa igreja pela primeira vez [...] vi mulher rodando, falei, "aquela mulher tá com Ogum". Aí falei, "pastor, isso aqui parece até a macumba da minha avó". Eu vim de lá, então vejo aquele povo rodando, pulando, cantando, a gente leigo, ignorante, a primeira visão acha que é a mesma coisa mas não é. [...] Tem pessoas que associam minha igreja com a macumba [porque as] pessoas rodam, marcham no poder e aquela coisa, e eu falo: aqui não é macumba não, heim, aqui é igreja. Agora, eu até respeito, porque quando eu tava lá na macumba, lá na macumba o povo também roda, o povo também faz aqueles negócios, eu sei. Só que se você ficar mais um pouquinho você vai ver que há uma diferença. Olhando assim até parece que você está numa macumba, mas tudo muda pelo que se é pregado, pelo que se é cantado, entendeu? Aqui, é o Espirito Santo de Cristo de Deus. Lá na macumba é os orixá, tem 
NEDER, Álvaro; et al. (2016) Música, religião e produção social de espaço em uma cidade operária - o caso da igreja da pastora Ana Lúcia em Belford Roxo, Rio de Janeiro. Per Musi. Ed. por Fausto Borém, Eduardo Rosse e Débora Borburema. Belo Horizonte: UFMG, n.34, p.132-176.

vários outros nomes, entendeu? Mas eu falei, vai ficando por aqui que você vai entender. (ANA LÚCIA, 2014)

No entanto, embora as manifestações exuberantes de musicalidade e corporalidade negra nessa igreja se distanciem discursivamente das práticas religiosas afrobrasileiras para buscarem se associar às divindades cristãs, o vigor dessas manifestações é utilizado pelos fiéis como índices seguros da presença dessas divindades. Conforme nos disse Elton Silveira, membro da congregação, a energia sentida pelos fiéis e músicos durante a dança entusiástica (repleta de referências às religiões de possessão afro-brasileiras) e a música em altos decibéis demonstra que o Espírito Santo se encontra ali: "Tem muitas igrejas hoje em dia que não sente a mesma unção que tem aqui, entendeu? Tem igrejas que já estão apagadas, né? Que o Espírito Santo não habita mais aquela igreja, entendeu?".

A gente vem para cultuar a Deus e para sentir a presença de Deus, né. [A maneira] como os louvores são entoados, a gente sente um âmbito, assim, muito espiritual. A presença de Deus é notória nesse lugar. E a Bíblia diz que o poder de Deus é que faz a diferença nas nossas vidas. Então, a presença de Deus é notória nesse lugar e nós sente a presença de Deus, e nós se alegra, e temos paz e alegria quando estamos na igreja (SILVEIRA, 2014).

Da mesma forma, o pastor Rafael Silva reforça a conexão verificada entre a música da igreja e a presença do Espírito Santo, salientando o fato de que se trata de uma música negra ao enumerar instrumentos percussivos:
[...] [o corinho] atrai não só os pentecostais, mas também muitas outras pessoas, porque além do corinho [...] há uma ação do Espírito Santo [...], você vê que não é só ali o tambor, porque o tambor, e o tantan e o violão sem a unção, né, torna-se uma coisa por apenas por usar, um corinho qualquer, mas quando você faz com unção e com a visão que a pastora Ana Lúcia tem, né, é isso aí e o que impacta e é o que traz, sabe, é o que atrai as pessoas. (SILVA, 2014)

Se a presença do Espírito Santo está relacionada a uma música embebida de significados raciais e de classe, é nosso dever, como pesquisadores, anotar tal valorização da diferença. Ao ser perguntado sobre quais são os gêneros musicais executados na igreja, o músico Gabriel Silva dos Santos declara que "É um ritmo diferente que a gente do movimento evangélico criamos. Misturamos pagode e forró. A música é do povo negro" (SANTOS, 2014). 0 músico André Casimiro da Silva 
NEDER, Álvaro; et al. (2016) Música, religião e produção social de espaço em uma cidade operária - o caso da igreja da pastora Ana Lúcia em Belford Roxo, Rio de Janeiro. Per Musi. Ed. por Fausto Borém, Eduardo Rosse e Débora Borburema. Belo Horizonte: UFMG, n.34, p.132-176.

refere, entre outros gêneros musicais, o forró, por causa da maciça migração nordestina na Baixada Fluminense. Reconhecendo a origem negra das músicas utilizadas pela banda da pastora, denominada Vem Comigo Dando Glória, estabelece uma clara dicotomia entre o "hinozinho da harpa" (música de matriz europeia) e músicas de origem negra: “A gente misturou... Antes era o hinozinho da harpa... o hino cristão... Mas começamos a colocar ritmo de rock, pagode, tem até funk! É um ritmo que eu particularmente gosto. Gosto do rock, funk, pagode..." (CASIMIRO DA SILVA, 2014). Enquanto isso, o músico Hélio Domingos dos Santos Marques também ressalta a predominância de músicas de origem negra, ao responder à pergunta sobre quais seriam os gêneros musicais executados na igreja:

0 mais marcante é o samba. Até porque a gente já teve ex-sambistas e ex-pagodeiros, mas em matéria de outros ritmos a gente tem o forró, na quinta feira, que é aquele mais metal, mais elétrico, a pessoa fica mais eufórica, então a gente tem dois tipos de ritmo aqui, e o outro é mais calmo, "adoração", como a gente costuma intitular. Então a gente tem três tipos de ritmo aqui na igreja, temos o mais calmo, temos o forró e o pagode. (CASIMIRO DA SILVA, 2014)

Para o músico Bruno dos Santos Silva, a música produzida ali é uma mescla de diferentes músicas negras:

Predominância pra nós aqui [...] nem nós conseguimos decifrar o que é de verdade, que é um suingado diferente, que é um ritmo diferente, então você não sabe se é um forró, se é um suíngue, se é um black. Então, ficou uma mistura que deu certo. Graças a Deus deu certo, nós temos colhido esses frutos.

[Você diria que essas músicas são uma contribuição da raça negra?]

São, são sim e nós temos visto a forma que o mundo trata a música, o estilo musical que veio.

[Você diria então que existe uma contribuição da raça negra?]

Existe, existe sim. Existe uma contribuição sim por que através da Bahia por exemplo, a capoeira, o axé, alguns estilos musicais que nós [usamos] que [...] os negros [...] que trouxeram, começaram, então tem sim uma grande influência. (SANTOS SILVA, 2014)

Já Hélio Domingos dos Santos Marques afirma que a música negra da igreja é a música da comunidade, que também é negra e pobre em sua maioria: "É que nossa comunidade é muito carente, então a maioria das pessoas é de cor negra. É a música 
NEDER, Álvaro; et al. (2016) Música, religião e produção social de espaço em uma cidade operária - o caso da igreja da pastora Ana Lúcia em Belford Roxo, Rio de Janeiro. Per Musi. Ed. por Fausto Borém, Eduardo Rosse e Débora Borburema. Belo Horizonte: UFMG, n.34, p.132-176.

da nossa comunidade, realmente" (MARQUES, 2014). Deve-se notar a classificação sociológica que associa à questão racial à pobreza, na fala de Marques.

No entanto, não é possível ser mais explícito e afirmativo nessa valorização da diferença e orgulho negro do que a própria pastora Ana Lúcia:

Raça negra, tantan, música... Eu sou negra! [muito enfática] Eu vim duma família negra! Família do pagode, da macumba, família de católicos, eu não posso dizer que não venho! Venho! Sou negra! Eu vim de lá [África], minha família, meus avós, é de lá! Sou negra, mas a minha música, o branco também canta! (ANA LÚCIA, 2014)

\section{E continua:}

Sou uma pessoa muito espontânea, gosto de ser festeira. Acho que esse negócio de ser festeira é coisa de preto mesmo. Que eu gosto de ser festeira, eu gosto de cantar, eu gosto de sambar, eu gosto de dançar, eu gosto de ser alegre, eu gosto de ajudar, entendeu? Isso não é por eu ser evangélica. Eu gosto muito de citar isso. (ANA LÚCIA, 2014)

A valorização é, inclusive, da beleza negra, conforme a pastora:

Eu dizia "vamos ali" a uma amiga, ela dizia "ah não vou não porque eu sou negra", e eu "qual o problema? Nós somos negonas bonitas, penteia esse cabelo, passa um batom, vambora! Às vezes o racismo parte do próprio negro. Tem muitos negros que têm vergonha de ser negro. Eu não tenho. Eu adoro ser negona! Eu adoro ser negona! Dou um jeitão no cabelo, boto umas roupas (faz gestos sensuais ao longo de seu corpo) de nossa! Sou bem pra cima! (ANA LÚCIA, 2014)

Perguntada se "é uma cultura para se ter orgulho?", responde Ana Lúcia: "Eu tenho orgulho. Eu amo ser quem eu sou. Eu amo e por que que eu amo? Não é porque a coisa é boa pra mim, eu amo porque a coisa não é só boa pra mim, é boa pras outras pessoas." É boa para outras pessoas, segundo explica, porque ela é vista como uma referência dentro de sua comunidade, ou mesmo mais além, quando ocupa as telas das TVs e computadores, superando a rejeição motivada pelo preconceito (de raça, classe e gênero) e encontrando seu lugar:

Sim, como negra, como pastora, como mulher, como mãe, como cantora, como lutadora, como guerreira, isso atrai o povo mesmo. Eu tenho aqui praticamente 15 homens que foram atraídos pela beleza dessa negona, por esse jeito expansivo de falar, por esse jeito maravilhoso de eu me dar com as pessoas, então realmente é isso, 
NEDER, Álvaro; et al. (2016) Música, religião e produção social de espaço em uma cidade operária - o caso da igreja da pastora Ana Lúcia em Belford Roxo, Rio de Janeiro. Per Musi. Ed. por Fausto Borém, Eduardo Rosse e Débora Borburema. Belo Horizonte: UFMG, n.34, p.132-176.

a minha cor, o meu jeito, de crioula, de negona, de alegre de falar, realmente atrai as pessoas [enquanto isso, as pessoas passam pela rua ao lado de seu templo, onde era feita a entrevista, mandando beijos a ela e se comunicando]. 0 povo me ama mesmo, o povo me abraçou; fui muito rejeitada [por outras denominações neopentecostais] mas estou conseguindo ocupar meu espaço. Um espaço maior. Uma aceitação melhor por causa do trabalho positivo que eu tenho empenhado na comunidade. (ANA LÚCIA, 2014)

\section{9 - Conclusão}

Fica, então, caracterizada a igreja como um espaço social onde questões raciais e de exclusão são importantes, bem como atitudes afirmativas que buscam confrontar esses problemas, sendo que a música ocupa lugar central nessa luta. Inicialmente demonstramos que a "música" (compreendida de maneira bem mais ampla do que o usual) atua de forma essencial na produção de um espaço social religioso. A seguir, evidenciamos, através de depoimentos dos participantes da igreja, que a questão racial negra é reconhecida por eles, e que a igreja e a "música" são representativas de uma comunidade negra. Neste mesmo passo, afastamos uma noção equivocada de que os fiéis são ouvintes passivos, ao desenvolvermos uma teorização que afirma a pastora, músicos e "música" como discursos de um coletivo, como articulações de uma agência social. Confirmamos, assim, que a "música" negra é importante para a produção de um espaço social de identidade negra, o que nos permite dizer que existe uma intenção, ainda que não articulada na forma de um discurso militante, desses fiéis, de se organizar em torno da questão negra.

No entanto, são visíveis as contradições verificadas com relação às condições objetivas de existência dos fiéis e as ideologias professadas na religião evangélica e até mesmo nas letras de música. Tais letras pregam uma atitude condizente com aquela predominante no neopentecostalismo, exortando o fiel a encontrar a "vitória" individual nas engrenagens do capitalismo. Como lembrou, oportunamente, a antropóloga Simone Luci Pereira em seguida à apresentação oral de nossa comunicação (que deu origem ao presente artigo) no XI Congresso de la IASPM-LA (International Association for the Study of Popular Music, Rama Latinoamericana): 
NEDER, Álvaro; et al. (2016) Música, religião e produção social de espaço em uma cidade operária - o caso da igreja da pastora Ana Lúcia em Belford Roxo, Rio de Janeiro. Per Musi. Ed. por Fausto Borém, Eduardo Rosse e Débora Borburema. Belo Horizonte: UFMG, n.34, p.132-176.

As letras dos "corinhos" (me lembro de uma que dizia "o meu milagre vai virar notícia") têm um caráter ou estão permeadas de questões que dizem respeito à cultura do consumo e midiática e da própria questão dos regimes de visibilidade e celebrização das culturas comunicacionais. Ou seja, têm uma afirmação contrahegemônica, mas também aderem a lógicas hegemônicas, num potencial muito ambíguo. (Pereira, 2014)

Concordando de antemão com Pereira a propósito da ambiguidade da mensagem ideológica, cumpre, entretanto, notar que são feitas críticas em bases semelhantes à música popular como um todo, ou seja: a de ser comercializada na forma mercadoria, produzindo a dominação das indústrias fonográficas em detrimento das populações e fortalecendo o ideário capitalista nas práticas sociais. Buscando compreender o potencial crítico que reside em produções marcadas pela ambiguidade, Álvaro Neder vem trabalhando há vários anos com o conceito de contradição na música popular, conforme explica:

\begin{abstract}
A contradição é compreendida, aqui, a partir da matriz psicanalítica, como fruto do embate entre pulsões destruidoras e criativas, inerentes aos sujeitos inseridos na cultura, e, a partir da teoria marxista, como o que poderia levar a uma transformação do modo de produção. Justifica-se, assim, o esforço analítico em não tentar resolver as contradições, testemunhando-se, ao contrário, sua proliferação. Pressupõe-se, neste livro, que as práticas culturais tornam-se tão mais transformadoras quanto mais contraditórias sejam. Por outro lado, por não haver determinação da "superestrutura" ideológica pela "infraestrutura" econômica, as canções possuem seu próprio nível de determinação, que diz respeito à construção das subjetividades. [...] Importam os efeitos das canções sobre as diversas lutas ideológicas, por intermédio do oferecimento de posições subjetivas, que podem ser politicamente inertes ou mobilizadoras. Se for assim, a medida do potencial transformador das canções é a quantidade de pessoas que envolvem, e a capacidade dessas práticas de gerar polêmica e debate entre as pessoas envolvidas. (Neder, 2014: 17)
\end{abstract}

E, com efeito, polêmica e debate surgem no contexto da prática musical demonstrada como altamente popular, envolvendo muitas pessoas. Como a questão da violência e do conflito está sempre presente no cotidiano dos entrevistados, segundo declaram, a música negra no culto é uma forma de luta contra o preconceito, ainda que esta luta esteja disfarçada ou ambígua. Numa sociedade que reprime de diversas formas violentas a expressão aberta de conflitos, é de se esperar que eles estejam camuflados. É justamente por isso que a música, como expressão simbólica destes conflitos - que tem trânsito social mais ou menos livre, dada sua 
NEDER, Álvaro; et al. (2016) Música, religião e produção social de espaço em uma cidade operária - o caso da igreja da pastora Ana Lúcia em Belford Roxo, Rio de Janeiro. Per Musi. Ed. por Fausto Borém, Eduardo Rosse e Débora Borburema. Belo Horizonte: UFMG, n.34, p.132-176.

polissemia -, assume tamanha importância como documento das lutas sociais dos negros e membros dos segmentos de baixa renda. Isso porque a música da igreja da pastora Ana Lúcia não está vinculada apenas à questão racial negra, estando conectada também aos setores subalternos não-negros: é bastante evidente, a partir da observação participante e declarações dos fiéis, que há uma identificação de classe entre a maioria dos frequentadores e os pastores, visto que quase todos são de baixa renda. A necessidade de usar os ganhos obtidos em suas pregações em outras igrejas de todo o Brasil e na venda de "quentinhas" para ajudar os fiéis necessitados e manter a igreja, como foi declarado pela pastora em dado momento, é importante para ressaltar isso. Inclusive, o preconceito de classe se soma ao preconceito de raça e ao preconceito de gênero em sua narrativa de superação - em outras igrejas as condições são menos ingratas:

Quando eu fui a Taubaté, onde eu fui ordenada pastora [...], começando a Igreja do Evangelho Pleno, com o bispo Paulo Ventura [...] ele disse, "você começou mais nova do que eu, e com a idade que você tem, tem uma igreja num lugar mais difícil do que eu tive a minha igreja. Então eu te parabenizo, Ana. Porque você sem marido, com filho adolescente, você pegar essa obra, que não é fácil."

[O que ele quis dizer com lugar mais difícil?]

Porque é dentro de uma comunidade. A dificuldade é financeira, a dificuldade financeira é muito difícil pra gente lidar. A gente ganhou um terreno há 5 anos, estamos aí querendo botar um telhado que é 4 mil reais, a gente não tem o dinheiro. [Descreve detalhadamente preços de benfeitorias e como é difícil fazê-las; diz o preço do aluguel que paga pela igreja e por sua moradia, que fica no segundo andar; descreve como tem tido mais convites depois de sua participação no programa Esquenta, e como ela divide esse dinheiro com sua congregação]. A igreja do Paulo Ventura é de Taubaté [descreve em detalhes a riqueza dessa outra igreja; fala da pobreza da igreja dela]. Está cada vez fica mais difícil, mas eu não desisto. Eu amo ser o que eu sou hoje! (ANA LÚCIA, 2014)

Portanto, os resultados desta pesquisa evidenciam um território social produzido ativa e afirmativamente como resposta e desafio à exclusão e preconceito racial e econômico, no qual a música é parte fundamental. A partir deste espaço musical e religioso, os fiéis da Pastora Ana Lúcia lutam simbolicamente pelos direitos de inclusão e cidadania, e pelo respeito por suas crenças e práticas.

\section{Referências}


NEDER, Álvaro; et al. (2016) Música, religião e produção social de espaço em uma cidade operária - o caso da igreja da pastora Ana Lúcia em Belford Roxo, Rio de Janeiro. Per Musi. Ed. por Fausto Borém, Eduardo Rosse e Débora Borburema. Belo Horizonte: UFMG, n.34, p.132-176.

1. ABRAHAMS, R. D. (1976). Talking black. Rowley, Mass.: Newbury House.

2. ADORNO, T.W. (1986). Teses sobre a sociologia da arte. In: COHN, Gabriel (org.). Theodor W. Adorno. S. Paulo: Ática.

3. ANA LÚCIA (pastora). (2014). Entrevista concedida a Álvaro Neder. Belford Roxo, 3 ago.

4. __ (2014). Vídeo com a pastora e seu grupo Gideões Vem Comigo Dando Glória. $8 \mathrm{~min} 36 \mathrm{~s}$ 2010. Disponível em: <https://www.youtube.com/watch?v=9h0y93yzSr0>. Acesso em: 27 ago.

5. ANAVI, I. (2014). Depoimento pessoal à pergunta “O que é Corinho de Fogo?" In: Yahoo! Respostas. Disponível em: https://br.answers.yahoo.com/question/index?qid=20121201125655AAo qY2L. Acesso em: 20 jul.

6. ARAÚJO, S. (1992). Acoustic labor in the timing of everyday life: a social history of samba in Rio de Janeiro (1917-1980). Tese de doutorado em etnomusicologia. Universidade de Illinois em Urbana-Champaign, EUA.

7. __ (2009). "Diversidade e desigualdade entre pesquisadores e pesquisados. Considerações teórico-metodológicas a partir da etnomusicologia". Desigualdade e diversidade - Revista de Ciências Sociais da PUC-Rio, n.4. Disponível em : (http://publique.rdc.pucrio.br/desigualdadediversidade/cgi/cgilua.exe/sys/start.htm?infoid=66\&si $\mathrm{d}=12$ ). Acesso em: 01/08/2014.

8. ___ et al. (2006). A violência como conceito na pesquisa musical; reflexões sobre uma experiência dialógica na Maré, Rio de Janeiro. In: Revista Transcultural de Música, v.10. Disponível em: < http://www.sibetrans.com/trans/articulo/148/a-violncia-como-conceitonapesquisamusical-reflexes-sobre-uma-experincia-dialogica-na-mare-riode-janeiro>. Acesso em: 01/08/2014.

9. BIRMAN, P. (1996). Cultos de possessão e pentecostalismo no Brasil: passagens. In: Religião e Sociedade, v.17(1-2), p.90-109.

10. BRACKETT, D. (2003). “James Brown's 'Superbad' and the Double-Voiced Utterance". In Middleton, R. (Ed.). Reading pop. Approaches to Textual Analysis in Popular Music. New York: Oxford.

11. BURDICK, J. (2001). Pentecostalismo e identidade negra no Brasil: mistura impossível? In: MAGGIE, Yvonne; REZENDE, Claudia Barcellos (Orgs.). Raça como retórica: a construção da diferença. Rio de Janeiro: Civilização Brasileira. 
12. CARDOSO, L.; TEIXEIRA, L.; LUZ, L. et al. (2013). "Vem Comigo Dando Glória"! Música e corporalidade negra no Templo da Pastora Ana Lúcia. Audiovisual, 14:34min. Disponível em: < https://www.youtube.com/watch?v=60D-FtQaaww>. Acesso em: 05 abr. 2016.

13. CAMBRIA, V. (2004). "Etnomusicologia aplicada e pesquisa ação participativa. Reflexões teóricas iniciais para uma experiência de pesquisa comunitária no Rio de Janeiro". Anais do V Congresso Latinoamericano da Associação Internacional para o Estudo da Música Popular. Disponível em: http://www.iaspmal.net/wpcontent/uploads/2011/12/VincenzoCambria.pdf. Acesso em: 5 fev. 2014.

14. CAMPOS, L.S. (2011). Pentecostalismo e protestantismo "histórico" no Brasil: um século de conflitos, assimilação e mudanças. In: Horizonte, Belo Horizonte, v.9, n.22, p.504-533.

15. CASIMIRO DA SILVA, A. (2014). Entrevista concedida a Álvaro Neder. Belford Roxo, 3 ago.

16. CASTORIADIS, C. (1991). A instituição imaginária da sociedade. São Paulo: Paz e Terra.

17. ___ (1999). Feito e a ser feito: as encruzilhadas do labirinto (v.V). Rio de Janeiro: DP\&A.

18. __ (1992). 0 mundo fragmentado: as encruzilhadas do labirinto (v.III). São Paulo: Paz e Terra.

19. (1997). World in fragments. Stanford: Stanford University Press.

20. CORINHOS. (2014). In: Wikipédia, a enciclopédia livre. Flórida: Wikimedia Foundation, $2014 . \quad$ Disponível em: <http://pt.wikipedia.org/w/index.php?title=Corinhos\&oldid=39301837>. Acesso em: 20 jul.

21. CUNHA, M.N. (2004). "Vinho novo em odres velhos": um olhar comunicacional sobre a explosão gospel no cenário religioso evangélico no Brasil. Tese (Doutorado em Ciências da Comunicação) - Universidade de São Paulo, Escola de Comunicação e Artes, Programa de Ciências da Comunicação. São Paulo: USP.

22. DOLGHIE, J.Z. (2007). Por uma sociologia da produção e reprodução musical do presbiterianismo brasileiro: a tendência gospel e sua influência no culto. Universidade Metodista de São Paulo. Doutorado em Ciências da Religião. São Bernardo do Campo.

23. FAUSTINI, J.W. (1973). Música e adoração. São Paulo: Metodista.

24. FREIRE, P. (1996). Pedagogia da autonomia. São Paulo: Paz e Terra. 
NEDER, Álvaro; et al. (2016) Música, religião e produção social de espaço em uma cidade operária - o caso da igreja da pastora Ana Lúcia em Belford Roxo, Rio de Janeiro. Per Musi. Ed. por Fausto Borém, Eduardo Rosse e Débora Borburema. Belo Horizonte: UFMG, n.34, p.132-176.

25. (1970). Pedagogia do oprimido. São Paulo: Editora Paz e Terra.

26. GATES Jr., H.L. (1988). The Signifying Monkey: a Theory of AfricanAmerican Literary Criticism. Oxford University Press.

27. GOURLAY, K.A. (1984). "The Non-Universality of Music and the Universality of Non-Music". The World of Music 26, n.2, p.25-39.

28. GOUVÊA, A. (2007). "Protestantismo no Brasil”. Revista USP, São Paulo, n.74, p.160-173.

29. GUBERMAN, R. M. (ed.). (1996). Julia Kristeva interviews. New York: Columbia UP.

30. HENNION, A. (2002). "Music and mediation: towards a new sociology of music". In: Clayton, M.; Herbert, T.; Middleton, R. (Eds.). The cultural study of music: a critical introduction. London: Routledge, 2002.

31. HOONAERT, E. (1978). Formação do catolicismo brasileiro, 1550-1800: ensaio de interpretação a partir dos oprimidos. 2 ${ }^{a}$ ed. Petrópolis: Vozes.

32. IBGE. (2014). Rio de Janeiro - Belford Roxo. Disponível em: http://cidades.ibge.gov.br/xtras/perfil.php?lang=\&codmun=330045\&searc $\mathrm{h}=$ rio-de-janeiro|belford-roxo|infograficos:-informacoes-completas. Acesso em: 29 abr.

33. KRISTEVA, J. (1998b). The subject in process. In: French; Lack (eds.), The Tel Quel reader. Nova York: Routledge, p.133-78.

34. pp.19-34.

. (1975). The subject in signifying practice. In: Semiotexte, v.1,

35.

(1998a). Psychoanalysis and imaginary. In: Silverman, H. (ed.).

Cultural semiosis: tracing the signifier. New York: Routledge.

36.___ (1976). "Signifying practice and mode of production". In: Edinbug Magazine [Edinburg Film Festival], p.64-76.

37. _ (1974). La révolution du langage poétique; l'avant-garde à la fin du XIXe siècle: Lautréamont et Mallarmé. Paris: Éditions du Seuil.

38.___ (1989). Language the unknown: an initiation into linguistics. Tradução Anne M. Menke. New York: Columbia UP. Título original: Le langage, cet inconnu.

39. (1980). Desire in language: a semiotic approach to literature and art. New York: Columbia UP.

40.___ (1969). Séméiotiké: recherches pour une sémanalyse. Paris: Editions du Seuil. 
41. LIMA, É.F.S. (1991). "Reflexões sobre a 'Corinhologia' brasileira atual". Boletim Teológico, Porto Alegre, Fraternidade Teológica Latino-Americana, n.5. Disponível em: <www.reocities.com/prgb_2000/coro.doc> Acesso em: $29 / 04 / 2014$.

42. LUHNING, A. (2001). Música, palavra-chave da memória. In: MATOS, C. N.; MEDEIROS, F. T.; TRAVASSOS, E. (Orgs.). Ao encontro da palavra cantada: poesia, música e voz. Rio de Janeiro: 7Letras, 2001.

43. MARQUES, H.D.S. (2014). Entrevista concedida a Álvaro Neder. Belford Roxo, 3 ago.

44. MOURA, C. (1994). Dialética radical do Brasil negro. São Paulo: Editora Anita.

45. MUSICULTURA. Música e sociabilidade na Maré. (2008). Maceió. Anais... Maceió: IV ENABET (Encontro Nacional da Associação Brasileira de Etnomusicologia), p.72-77.

46. NASCIMENTO, A.L. (2014). Entrevista concedida a Álvaro Neder. Belford Roxo, 3 ago.

47. NEDER, A. (2014). Enquanto este novo trem atravessa o Litoral Central: Música popular urbana, latino-americanismo e conflitos sobre modernização em Mato Grosso do Sul. 1. ed. Rio de Janeiro: Mauad.

48. NEDER, A.; BARROS, D.; CAETANO, R. MATOS, M.C.; KOPP, R.P.; FRANÇA, D.; SUED, P.; FLORA, M. (2014). Música Negra no Templo da Pastora Ana Lucia. Audiovisual, 5:18min. Disponível em: < https://www.youtube.com/watch?v=otBf_gMne6U>. Acesso em: 05 abr. 2016.

49. NETTL, B. (2005). The study of ethnomusicology: twenty-nine issues and concepts. Champaign: University of Illinois Press.

50._- (1984). Western Musical Values and the Character of Ethnomusicology. The World of Music 26, n.1, p.29-42.

51. NUNES, A.C. (2014). Entrevista concedida a Álvaro Neder. Belford Roxo, 3 ago.

52.0 QUE SIGNIFICA "RETETÉ"? (2014). Disponível em: http://perguntas.gospelprime.com.br/o-que-significa\%E2\%80\%9Cretete\%E2\%80\%9D/. Acesso em: 01 jul.

53. PEREIRA, S.L. (2014). Intervenção oral após apresentação da comunicação deste caso pelos autores no XI Congresso de la IASPM-LA, enviada por e-mail pessoal em $22 \mathrm{dez}$. 
54. PINHEIRO, M.L. (2009). "Dinâmicas da religiosidade: experiências musicais, cor e noção de sagrado". López, L.Á.; Thylefors, M.; Wedel, J. (Orgs.). Representaciones $y$ expresiones religiosas afrolatinoamericanas. Stockholm Review of Latin American Studies, n.4.

55. SANCHIS, P. (1999). "O campo religioso contemporâneo no Brasil”.Oro, A. P.; Steil, C. A (Orgs.) Globalização e religião. Petrópolis: Vozes/ Porto Alegre: Universidade Federal do Rio Grande do Sul, $2^{\underline{a}}$ ed.

56. SANTIAGO, S. (2000). Caetano Veloso enquanto superastro. In: Uma literatura nos trópicos. 2a ed. Rio de Janeiro: Rocco, p.143-63.

57. SANTOS SILVA, B. (2014). Entrevista concedida a Álvaro Neder. Belford Roxo, 3 ago.

58. SANTOS, E.C. (2012). A situação das cidades do estado do Rio de Janeiro: primeiros resultados do Censo 2010. Relatório de Pesquisa. Grupo de Pesquisa Educação Infantil e Políticas Públicas (GREIPP). UNIRIO. Disponível em: $<$ http://sfb.org.br/br/wpcontent/uploads/2013/02/Levantamento_Dados_IBGE_2010_Final.docx>. Acesso em: 29 abr.

59. SANTOS, G.S. (2914). Entrevista concedida a Álvaro Neder. Belford Roxo, 3 ago.

60. SILVA, R. (2014). Entrevista concedida a Rodrigo Caetano e Daniel Barros. Belford Roxo, $10 \mathrm{abr}$.

61. SILVA, V.G. (2007). Neopentecostalismo e religiões afro-brasileiras: Significados do ataque aos símbolos da herança religiosa africana no Brasil contemporâneo. Mana [online], vol.13, n.1, p.207-236.

62. SILVEIRA, E. (2014). Entrevista concedida a Rodrigo Caetano e Daniel Barros. Belford Roxo, 10 abr.

63. SIMÕES, M.R. (2011). Ambiente e sociedade na Baixada Fluminense. Mesquita, RJ: Entorno.

64. SMALL, C. (1999). El musicar: un ritual en el espacio social. In: Transcultural Music Review 4.4 Disponível em: <http://www.sibetrans.com/trans/trans4/small.htm>. Acesso em: 04 mai. 1999.

65._._. (1987). Music of the common tongue: survival and celebration in afro-american music. Nova York: Riverrun.

66. THIOLLENT, M. (2008). "Perspectivas da pesquisa-ação em etnomusicologia: anotações e primeiras indagações”. ARAÚJO, S.; PAZ, G.; CAMBRIA, V. (Orgs.) Música em debate: perspectivas interdisciplinares. Rio de Janeiro: Mauad $\mathrm{X}$ : FAPERJ. 
NEDER, Álvaro; et al. (2016) Música, religião e produção social de espaço em uma cidade operária - o caso da igreja da pastora Ana Lúcia em Belford Roxo, Rio de Janeiro. Per Musi. Ed. por Fausto Borém, Eduardo Rosse e Débora Borburema. Belo Horizonte: UFMG, n.34, p.132-176.

Nota sobre os coautores

Álvaro Neder é Professor Associado de Etnomusicologia no Instituto Villa-Lobos e no Programa de Pós-Graduação em Música (mestrado e doutorado) da Universidade Federal do Estado do Rio de Janeiro/UNIRIO.

Rui Pereira Kopp é estudante de Licenciatura em Música no Instituto Villa-Lobos.

Daniel Barros, Daniela França, Maria Clara de Matos, Mauricio Flora, Priscilla Sued e Rodrigo Caetano são estudantes de Graduação em Produção Cultural no Instituto Federal do Rio de Janeiro/IFRJ, Campus Nilópolis (Baixada Fluminense). 